\title{
International Transmission with Heterogeneous Sectors
}

\author{
By KeYU Jin AND NAN LI*
}

\begin{abstract}
This paper documents new facts about the behavior of capital-and labor-intensive goods over the business cycle and also identifies a mechanism that generates international investment co-movement through shifting compositional changes of production and trade across sectors. Our model's quantitative predictions not only match aggregate and sectoral statistics but also generate empirically plausible sectoral composition effects. Finally, we show that essential segments of the transmission process receive empirical support. (JEL E23, E24, E32, F44, L16)
\end{abstract}

\section{$\mathrm{R}$} esearch on international real business cycle (IRBC) theory, which is based on modeling the stochastic growth of large open economies, typically assumes homogeneous production factor intensities across different goods. In reality, however, some sectors use capital—and others, labor-more intensively in the production process. In addition, these factor intensity differences are large across sectors.

A close inspection of the data reveals distinctive patterns that distinguish labor-intensive from capital-intensive sectors. In particular, there are systematic changes in the composition of production of capital- and labor-intensive sectors over the business cycle; these changes are manifest in the strongly countercyclical share of production in capital-intensive sectors (see Figure 1). Between 1977 and 2013, the correlation of the cyclical components of capital-intensive sectors' production share and real gross domestic product (GDP) in the United States is -0.82 , as corroborated by a high correlation of -0.58 between their respective employment shares.

Equally striking is the behavior of the relative price of capital-intensive goods to labor-intensive goods over business cycles. As shown in Figure 2, this relative price is strongly proyclical and tracks business cycles closely (correlation $=0.70)$.

\footnotetext{
* Jin: Department of Economics, London School of Economics, Houghton Street, London, WC2A 2AE, UK (email: k.jin@1se.ac.uk); Li: Research Department, International Monetary Fund, 700 19th Street NW, Washington, DC 20431 (email: nli@imf.org). For many helpful comments, we are grateful to the anonymous referees, Francesco Caselli, Nicolas Coeurdacier, Emmanuel Farhi, Gita Gopinath, Stéphane Guibaud, Patrick Kehoe, Fabrizio Perri, and Kenneth Rogoff, as well as seminar participants at BEA, CEPR International Macro Conference, LSE, Georgetown University, George Washington University, Science Po Paris, Tsinghua University, University of Wisconsin, NBERIFM Summer Institute, Society of Economic Dynamics Meeting, AEA-IEFS Meeting, the Federal Reserve Board, Federal Reserve Bank of Dallas, Federal Reserve Bank of Minneapolis, and the IMF. Thanks also to Xiaohan Ma for providing excellent research assistance. The views expressed herein are those of the authors and should not be attributed to the IMF, its Executive Board, or its management.

Go to https://doi.org/10.1257/mac.20150379 to visit the article page for additional materials and author disclosure statement(s) or to comment in the online discussion forum.
} 


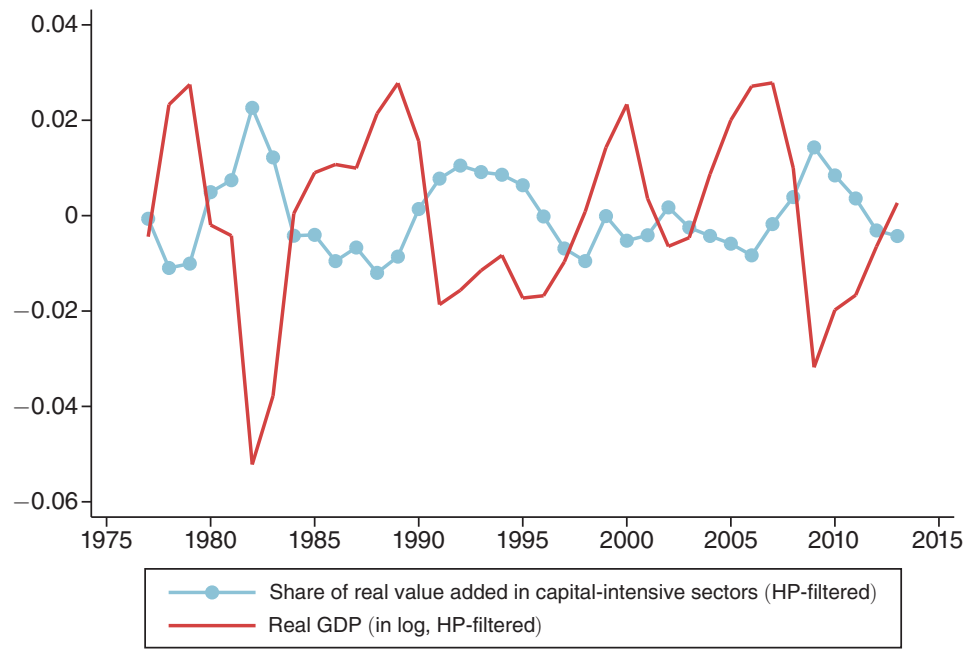

Figure 1. Sectoral Compositional Changes and the Business Cycle

Notes: This figure plots, in relation to the business cycle, the cyclical components of the share of real value-added in capital-intensive sectors. All private sectors at the most disaggregated level (two-four-digit levels of the NAICS) are divided into two larger sectors-namely, a labor-intensive sector and a capital-intensive sector-according to their respective labor shares in value-added. Additive real value-added (at constant prices) in each disaggregated sector is then aggregated into these two sectors. See Appendix A for more details.

Source: US Bureau of Economic Analysis Industry Economic Accounts and National Accounts, 1977-2013

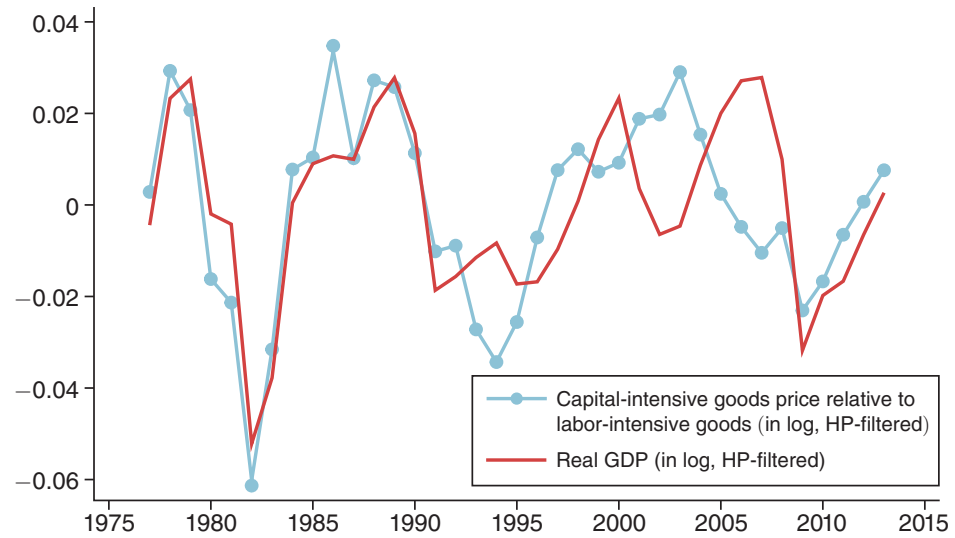

Figure 2. Sectoral Relative Price Changes and the Business Cycle

Notes: This figure plots, in relation to the business cycle, the cyclical components of the relative price of goods produced by capital-intensive sectors as compared with labor-intensive sectors. All private sectors at the most disaggregated level (two-four-digit levels of the NAICS) are divided into two larger sectors-namely, a labor-intensive sector and a capital-intensive sector-according to their respective labor shares in value-added. Sectoral price is calculated as the ratio of nominal value-added to real value-added. See Appendix A for more details.

Source: US Bureau of Economic Analysis Industry Economic Accounts and National Accounts, 1977-2013 


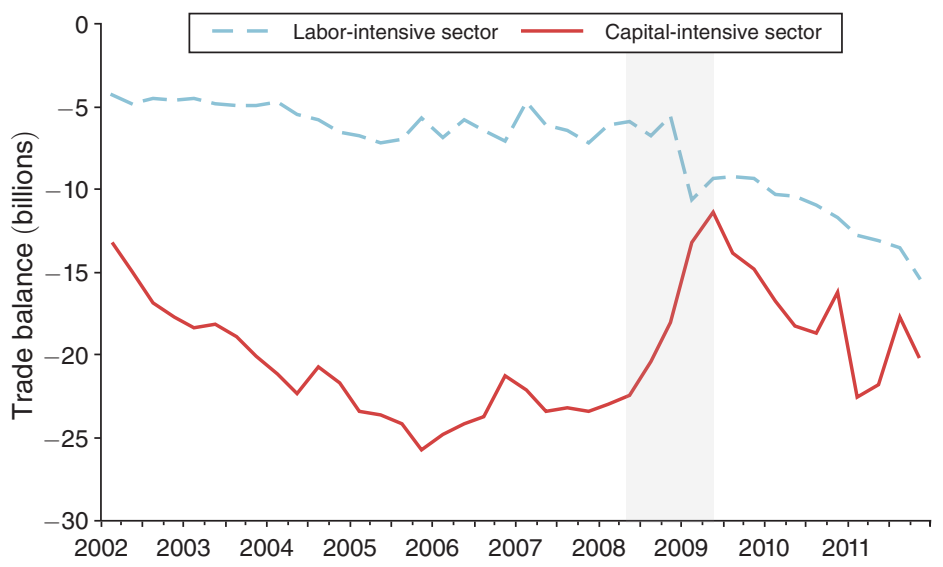

Figure 3. US Manufacturing Trade Balance with EU15 in CaPital- and Labor-Intensive Sectors

Notes: Manufacturing sectors at the most disaggregated level (NAICS six-digit) are aggregated into two larger groups - a capital-intensive sector and a labor-intensive sector-according to their respective labor shares in industry value-added; calculations are based on National Bureau of Economic Researh (NBER) data for manufacturing industries. Quarterly export and import data are seasonally adjusted using the Census X-12 method. See Appendix A for more details.

Source: US International Trade Commission

Booms (recessions) are associated with a rise (fall) in the relative price of capital-intensive goods. ${ }^{1}$

Another pattern is that the composition of trade of capital-and labor-intensive goods can also vary over the business cycle. The Great Recession of 2008-2009 is a case in point. Along with the collapse of trade overall during this period (which itself has spurred considerable research), there occurred a notable change in the composition of trade: the net exports of capital-intensive goods from the United States to the EU15 economies ${ }^{2}$ increased by $\$ 11$ billion, while that of labor-intensive sectors decreased by $\$ 4$ billion (see Figure 3). This decline was accompanied by a significant drop (of about 10 percent) in the price of capital-intensive goods relative to labor-intensive goods from August 2008 through December 2009.

Motivated by these patterns on the behavior of capital- and labor-intensive goods over the business cycle, this paper endeavors to achieve two goals. The first goal is to investigate the business cycle properties of a multi-sector stochastic growth model and to establish, thereby, whether (or not) the observed domestic compositional changes across different sectors accord with the empirical patterns described previously. A new transmission mechanism of real business cycle shocks across countries arises - through the relative price of capital to labor-intensive goods. This mechanism amounts to a channel through which shocks are positively

\footnotetext{
${ }^{1}$ These patterns are highly robust across many OECD industrial economies. The average correlation between the real value-added share of capital-intensive sectors and business cycles is - 0.63 - and between the employment share and business cycles is -0.53 - for the OECD economies in our sample. Appendix A provides more details on our definition of capital- and labor-intensive sectors.

${ }^{2}$ That is, the economies of Austria, Belgium, Denmark, Finland, France, Germany, Greece, Ireland, Italy, Luxembourg, the Netherlands, Portugal, Spain, Sweden, and the United Kingdom.
} 
transmitted across countries, by which we mean that investment and output tend to move together across countries in response to country-specific productivity shocks. That dynamic leans against the standard model, under which investment tends to flow toward the more productive economy and causes investment to fall abroad-a "resource allocation" effect.

The paper's second goal is to assess the quantitative properties of our multi-sector model by examining and then empirically assessing both aggregate and sectoral statistics. The strategy we adopt is (i) to estimate the model based on the behavior of sectoral production variables and aggregate variables in the US data and (ii) to evaluate the model in terms of its ability to account for the observed international co-movement in investment and output across countries.

The mechanism proposed in this paper relies on the interaction between factor-trade dynamics and macroeconomic forces. A country (Home) that experiences a country-specific positive shock expands disproportionately its labor-intensive sector, causing the world supply of labor-intensive goods to increase. The Foreign economy, which now faces a higher relative price of capital-intensive goods, shifts resources to that sector. This shift in the Foreign country's composition of production and exports in favor of capital-intensive sectors leads to a rise in those sectors' aggregate demand for investment. That rise, in turn, induces Home to allocate investment resources not only to its domestic economy but also to the Foreign economy, whose production has become more capital intensive-a "domestic composition" effect. In Foreign, the combination of its investment inflows and greater production of capital-intensive goods raises its GDP. We show that under certain conditions (which are met by the data), this trade-induced investment flow dominates quantitatively the standard resource allocation effect across countries and thus generates positive international co-movement.

We employ a two-country stochastic growth model in which sectors differ by factor intensity. All intermediate goods are produced by each country (i.e., there is no ex ante specialization), and are separated into labor-intensive goods and capital-intensive goods. Although we focus on productivity shocks, which can disproportionately affect the labor- and capital-intensive sectors, both preference shocks and demand shocks are also permitted.

It is important to note that the main endogenous force hinges on the Foreign economy's response to the Home productivity shock. By expanding more its capital-intensive sector-which requires more investment-rather than just any sector, the demand for investment rises in aggregate. In the absence of factor intensity differences across goods, international investment correlations are still negative; this result stems from the strong force sending investment toward countries that are more productive.

Indeed, the mechanism that brings about international co-movement differs from that in the Armington model, which yields international output co-movement but not (under plausible parameters) international investment co-movement. As shown by Heathcote and Perri (2002), positive investment co-movement does not arise in a two-good Armington model with complete markets or with a bond economy, but arises under complete financial autarky (i.e., when the resource allocation effect is shut off). 
In a model with endogenous incomplete markets, where international loans are imperfectly enforceable, Kehoe and Perri (2002) demonstrate that the need to satisfy enforcement constraints significantly reduces the amount of investment in a country hit by a positive and persistent shock; the mechanism delivers a foreign and domestic investment co-movement. In contrast to Kehoe and Perri's work, the endogenous mechanism that we propose is induced by factor proportions-based trade and is independent of the asset market's structure. Other papers that successfully account for international output and investment co-movement-in somewhat different settings_-include Benigno and Thoenissen (2008) and Corsetti, Dedola, and Leduc (2008). In the model of Corsetti, Dedola, and Leduc (2008), the appreciation in the terms of trade can induce negative wealth effects that raise the labor effort in Foreign, bringing about positive international co-movement. Our mechanism differs in that it relies neither on international asset market structure nor the extent to which shocks worldwide are correlated; instead, our mechanism is driven by capital's impetus to flow toward the country whose capital-intensive sector is expanding more. ${ }^{3}$

This paper does not offer additional insight for the "consumption-output anomaly" beyond what has already been established via models with limited risk sharing (Baxter and Crucini 1995; Kollmann 1996; Heathcote and Perri 2002; Kehoe and Perri 2002). Nor does this paper identify unique forces capable of generating a strong international employment correlation - as in Karabarbounis (2014), for example. ${ }^{4}$ Of greatest relevance for the mechanism we describe is the price of capital-intensive relative to labor-intensive goods. We show that this ratio exhibits robust patterns across most OECD countries and is about as volatile as US GDP. Over the period 1977-2013, the standard deviation of the $(\log )$ relative price of capital-intensive goods to labor-intensive goods in the United States is 2.09, as compared with an aggregate GDP volatility of 1.92 . The cyclicality of this relative price is also distinct and robust: the contemporaneous correlation between the cyclical component of the relative price of capital- to labor-intensive goods and US GDP is 0.70 . Similar patterns hold for OECD countries. ${ }^{5}$

We then use the data to assess each segment of the transmission channel. When examining the case in which sectors are divided by their factor intensity, we find that according to US data: (i) booms (recessions) are associated with a greater expansion (contraction) of its labor-intensive sector as compared with its capital-intensive sector-a pattern that holds for both inputs and outputs. This evidence establishes the domestic composition effect needed to instigate our international transmission channel; (ii) the relative prices of sectors that use labor input

\footnotetext{
${ }^{3}$ Corsetti, Dedola, and Leduc (2008) study a two-country, incomplete markets model featuring Armington-type trade; these authors focus on the puzzle first posed by Backus and Smith (1993). Any appreciation in the terms of trade strengthens the co-movement by inducing a negative wealth effect abroad and thus increasing labor effort there.

${ }^{4}$ Karabarbounis (2014) incorporates a "labor wedge," or the gap between the marginal product of labor and the marginal rate of substitution of leisure for market consumption, into the workhorse IRBC model—à la Backus, Kehoe, and Kydland (1992) — to account for several open-economy puzzles. However, investment correlations are still negative across countries.

${ }^{5}$ The peak cross-correlation between (normalized) capital-intensive prices and the business cycle is 0.25 for Canada, 0.44 for Denmark, 0.45 for Finland, 0.69 for Germany, 0.56 for Hungary, 0.49 for Italy, 0.65 for the Netherlands, and 0.27 for the United Kingdom.
} 
more intensively tend to be more countercyclical; (iii) that the US's net exports of capital-intensive goods to OECD economies tend to be more countercyclical than those of labor-intensive goods. Finally, OECD cross-country evidence allows us to make two additional observations. First, domestic booms (recessions) are associated with greater domestic expansion (contraction) in labor-intensive sectors, whereas foreign booms (recessions) are associated with greater domestic expansion (contraction) in capital-intensive sectors. Second, in both the Home and the Foreign economy, booms (recessions) are associated with a fall (rise) in the relative price of labor-intensive goods; this dynamic is consistent with the international propagation mechanism that our theory highlights.

A few points merit mention here. First, distinguishing sectors based on the factor intensity of their production is not equivalent to categorizing sectors based on their tradability (i.e., tradables versus non-tradables) or durability (durables versus nondurables). Contrary to widely held assumptions, neither durable goods nor capital goods are distinctively capital intensive, and non-tradable goods are not distinctively labor intensive. ${ }^{6}$ The IRBC literature has focused mainly on the dichotomous grouping of sectors by tradability or durability, and the application of this approach has been as wide-ranging as its implications are far-reaching (see, among others, Stockman and Tesar 1995; Engel and Wang 2011). We propose an alternative way of dissecting the sectors to help shed light on some empirical peculiarities.

Second, the evidence we present may challenge some preconceived notionsfor instance, that factor proportions trade cannot occur over the business cycle or that such trade cannot occur among industrialized economies. First, our theory does not predict factor content trade in the medium or long run. In our model economy, compositional changes in production and trade are driven by temporary productivity shocks rather than by factor endowment differences, which are absent among ex ante symmetric countries. All that is required, and what is paramount, is for the factor intensity of trade to be unsynchronized, across industrialized countries, over the business cycle. The data confirm that trade in both capital- and labor-intensive goods is sufficiently volatile to support our model's positive transmission mechanism.

Third, one may doubt the possibility of short-term sectoral reallocations. Yet it is important to realize that compositional changes stem primarily from the flow of investment, which displays considerable versatility and mobility in being directed to productive projects. ${ }^{7}$ The employment reallocation entailed by our model is both quantitatively small and consistent with data-based observations. Overall, in fact, the size of compositional changes — and the magnitude of factor proportions trade predicted by our quantitative model are in line with the data. The implication is that

\footnotetext{
${ }^{6}$ Sector-level data do not support a clear relationship between the durability or tradability of a good with the factor intensity of its production. Durable goods can be relatively labor intensive, as in the case of computer and electronic products, but they can also be capital intensive, as with electrical equipment and appliances. Similarly, non-tradable goods can be capital intensive; examples include utilities as well as legal and financial services. Note also that the conventional separation of capital goods and consumption goods is based on their end use, not on the intensity of input factors.

${ }^{7}$ Capital does not flow across sectors; rather, it is aggregate investment distributed across a country's sectors that augments or reduces the capital stock in each particular sector. In that sense our model is intrinsically different from a Heckscher-Ohlin model, which allows for instantaneous reallocation of capital stock across sectors. Specifications of that type are closer to a "specific factors" model with capital accumulation.
} 
no unrealistic extent of compositional changes and trade over the business cycle is required in order for our channel to operate.

Finally, this paper assumes the existence of a rudimentary motive for trade. We believe that it is by keeping the structure of trade simple that its interactions with macroeconomic forces are made most transparent. We are interested in how one realistic aspect captured by the data-factor intensity differences across sectorsaffects the international business cycle. Nonetheless, extensions of the model to allow for richer structures of trade structures so as to account for other features of the data is straightforward.

By endogenizing the trade patterns in an international business cycle context, this paper joins forces with those seeking to bridge the gap between IRBC theory and international trade theory. Burstein, Kurz, and Tesar (2008) examine the role played by vertically integrated, production-sharing trade in synchronization of the international business cycle. Ghironi and Melitz (2005) incorporate Melitz's (2003) model of trade with monopolistic competition and heterogeneous firms in a business cycle context for the purpose of explaining endogenous, persistent deviations from purchasing power parity. Cuñat and Maffezzoli (2004) study the business cycle properties of a two-country model with Heckscher-Ohlin trade and where countries are characterized by asymmetric factor endowments. While focusing on a different transmission mechanism from ours, these authors explain why the correlation between the terms of trade and income can be positive or negative for different countries. 8 In a two-country, two-sector, overlapping generations model, Jin (2012) derives theoretical results on the determinants of international capital flows-as driven by factor proportions trade-to address the question of why capital flows from "poor" to "rich" countries. The lack of empirical evidence on the behavior of capital- versus labor-intensive sectors over the business cycle in these papers reflects a gap in the literature that our research here is intended to fill.

The paper proceeds as follows. Section I extends the standard framework of a large open economy to incorporate multiple sectors with heterogeneous factor intensities. Section II presents our calibration and estimation of the model before examining its dynamic and quantitative properties. In Section III, we investigate the model's key implications using sectoral data at the most disaggregated level available. Section IV concludes.

\footnotetext{
${ }^{8}$ In fact, the paper by Cuñat and Maffezzoli (2004) differs from our work along three dimensions: the transmission mechanism proposed, the empirical investigation undertaken, and the key questions pursued. Their use of total factor productivity shocks in combination with asymmetric endowments across countries generates different initial trade patterns that do not yield the domestic composition effect we need to instigate our propagation mechanism. In the absence of such effects, positive co-movement in inputs and outputs does not emerge in their setting. In their main experiment, the authors examine an increase in productivity in the capital-abundant country. Since this increase in productivity raises the country's capital and labor (in efficiency units) by the same proportions, the world's capital/labor ratio (in efficiency units) also rises. However, in this economy any increase in the labor force or in productivity reduces the world's capital-labor ratio upon impact. Different production and trade patterns ensue, and the resource-shifting effect remains the dominant force in their model.
} 


\section{Model}

\section{A. Preferences and Technologies}

Consider a two-country world, Home and Foreign, each populated by a large number of identical and infinitely lived consumers. The countries produce and trade the same type of intermediate goods $i=1, \ldots, m$, conveniently indexed by their labor intensity: $1-\alpha_{i}>1-\alpha_{j}$ for $i>j .{ }^{9}$ Preferences and technologies are assumed to have the same structure across countries.

In each period $t$, the world economy experiences one of finitely many events $s_{t}$. Let $s^{t}=\left(s_{0}, \ldots, s_{t}\right)$ denote the history of events up to and including period $t$. At time 0 , the probability of any particular history $s^{t}$ is $\pi\left(s^{t}\right)$. Consumers in country $j$ have the standard preferences

$$
\sum_{t=0}^{\infty} \sum_{s^{t}} \pi\left(s^{t}\right) \beta^{t} \exp \left(\lambda_{t}\right) U\left(c^{j}\left(s^{t}\right), l^{j}\left(s^{t}\right)\right),
$$

where $c^{j}\left(s^{t}\right)$ denotes consumption per capita and where $l^{j}\left(s^{t}\right)$ denotes labor at time $t$ following history $s^{t}$ in country $j$. The terms $\beta$ and $\lambda_{t}$ represent, respectively, a subjective discount factor and an intertemporal preference shock. To allow for varying degrees of income, we consider the general form of preferences proposed by Jaimovich and Rebelo (2009):

$$
U(c, l)=\frac{\left[c\left(s^{t}\right)-\kappa l\left(s^{t}\right)^{\psi} x\left(s^{t}\right)\right]^{1-\sigma}-1}{1-\sigma}
$$

where $x\left(s^{t}\right)=c\left(s^{t}\right)^{\nu} x\left(s^{t-1}\right)^{1-\nu}$. This particular preference specification nests two special cases of utility functions widely used in the real business cycle literature: the preference specification of Greenwood, Hercowitz, and Huffman 1988 ( or "GHH" hereafter), equivalent to $\nu=0$; and that of King, Plosser, and Rebelo 1988 (or "KPR"), equivalent to $\nu=1$.

The production technology employs capital and labor to produce an intermediate good $i$ in country $j$ :

$$
Y_{i}^{j}\left(s^{t}\right)=A_{i}^{j}\left(s^{t}\right)\left(K_{i}^{j}\left(s^{t-1}\right)\right)^{\alpha_{i}}\left(l_{i}^{j}\left(s^{t}\right)\right)^{1-\alpha_{i}},
$$

where $0<\alpha_{i}<1$. We use $Y_{i}^{j}\left(s^{t}\right)$ to denote the gross production of good $i$ in $j$ following $s^{t}$ and use $K_{i}^{j}\left(s^{t-1}\right)$ for the capital stock in sector $i$ of country $j$. Production of intermediate goods is subject to a country- and sector-specific random shock $A_{i}^{j}\left(s^{t}\right)$, which follows an exogenous stochastic process.

\footnotetext{
${ }^{9}$ We focus on the case in which countries do not completely specialize in production.
} 
Intermediate goods are combined (with an elasticity of substitution $\theta$ ) to form a unit of final good, which is used for two purposes: consumption, $c^{j}\left(s^{t}\right)$; and investment, $I^{j}\left(s^{t}\right)$. The consumption good takes the form

$$
c^{j}\left(s^{t}\right)=\left[\sum_{i=1}^{m} \gamma_{i}^{1 / \theta}\left(c_{i}^{j}\left(s^{t}\right)\right)^{(\theta-1) / \theta}\right]^{\theta /(\theta-1)},
$$

where $c_{i}^{j}\left(s^{t}\right)$ is the consumption demand for good $i$ in country $j$; the share parameters satisfy both $\sum_{i} \gamma_{i}=1$ and $\theta>0$. The investment good in sector $i$ takes the same form as that of the consumption good

$$
I_{i}^{j}\left(s^{t}\right)=\left[\sum_{k=1}^{m} \gamma_{k}^{1 / \theta}\left(z_{k i, t}^{j}\left(s^{t}\right)\right)^{(\theta-1) / \theta}\right]^{\theta /(\theta-1)},
$$

where $z_{k i, t}^{j}\left(s^{t}\right)$ denotes the amount of good $k$ used for investment in the $i$ th sector of $j$. Aggregate investment in country $j$ at $s^{t}$ is $I^{j}\left(s^{t}\right)=\sum_{i} I_{i}^{j}\left(s^{t}\right)$.

The evolution of capital stock in sector $i$ of country $j$ is subject to a quadratic adjustment cost, and is described by the following expression:

$$
K_{i}^{j}\left(s^{t}\right)=(1-\delta) K_{i}^{j}\left(s^{t-1}\right)+I_{i}^{j}\left(s^{t}\right) \frac{b_{i}}{2} K_{i}^{j}\left(s^{t-1}\right)\left(\frac{K_{i}^{j}\left(s^{t}\right)}{K_{i}^{j}\left(s^{t-1}\right)}-1\right)^{2}
$$

here $\delta$ denotes the depreciation rate, and $b_{i}$ is the adjustment cost parameter. 10

Intermediate goods are traded across countries, with $p_{i}\left(s^{t}\right)$ denoting the intermediate good's price relative to that of the final good. We normalize the price of the final good $P\left(s^{t}\right)$ to 1 such that

$$
P\left(s^{t}\right)=\left[\sum_{i=1}^{m} \gamma_{i} p_{i}\left(s^{t}\right)^{1-\theta}\right]^{1 /(1-\theta)} \equiv 1
$$

The consumption and investment demands are, respectively,

$$
\begin{gathered}
c_{i}^{j}\left(s^{t}\right)=\gamma_{i}\left(p_{i}\left(s^{t}\right)\right)^{-\theta} c^{j}\left(s^{t}\right), \\
z_{k i}^{j}\left(s^{t}\right)=\gamma_{k}\left(p_{k}\left(s^{t}\right)\right)^{-\theta} I_{i}^{j}\left(s^{t}\right) .
\end{gathered}
$$

${ }^{10}$ This adjustment cost, in combination with uninsured risks, helps break the equilibrium factor price equalization across countries. 


\section{B. Budget Constraints and Asset Markets}

We consider an economy in which the only asset that is traded internationally is a single, non-state-contingent bond. The budget constraints associated with the consumer's problem in this economy are

$$
\begin{aligned}
& c^{j}\left(s^{t}\right)+I^{j}\left(s^{t}\right)+q\left(s^{t}\right) B^{j}\left(s^{t}\right) \\
& \quad=B^{j}\left(s^{t-1}\right)+w^{j}\left(s^{t}\right) l^{j}\left(s^{t}\right)+r^{j}\left(s^{t}\right) K^{j}\left(s^{t-1}\right)-\phi \frac{\left(B^{j}\left(s^{t}\right)\right)^{2}}{2} .
\end{aligned}
$$

In this expression, $q^{j}\left(s^{t}\right)$ is the price of the noncontingent bond at $t$ that pays one unit of the consumption good at $t+1$ regardless of the state of the world, $B^{j}\left(s^{t}\right)$ denotes the amount of bonds purchased at $t$ by a consumer in country $j$, and $\phi$ is the parameter governing the costs of international bond adjustment. Clearing of the international bond market requires that $\sum_{j} B^{j}\left(s^{t}\right)=0$ for all histories $s^{t}$.

\section{Market-Clearing Conditions}

Markets for intermediate goods clear when the global demand of each sectoral good $i$ equals its global supply:

$$
\sum_{j=H, F} c_{i}^{j}\left(s_{t}\right)+\sum_{j=H, F} \sum_{k=1}^{m} z_{i, k}^{j}\left(s^{t}\right)=\sum_{j=H, F} Y_{i}^{j}\left(s^{t}\right) .
$$

This equality, when combined with the consumption and investment demand in (8) and (9), yields the relative price of any two intermediate goods $i$ and $k$ :

$$
\frac{p_{i}\left(s^{t}\right)}{p_{k}\left(s^{t}\right)}=\left(\frac{\gamma_{i}}{\gamma_{k}} \frac{\sum_{j} Y_{k}^{j}\left(s^{t}\right)}{\sum_{j} Y_{i}^{j}\left(s^{t}\right)}\right)^{1 / \theta} .
$$

This expressions indicates that a greater world supply of good $k$ relative to good $i$ lowers the former's relative price. In the two-sector example, a greater supply of labor-intensive goods will increase the international relative price of capital-intensive goods. In the face of that higher price, the Foreign economy will tend to shift its resources toward the capital-intensive sector. This finding is analogous to the well-known result from the specific factors model of trade.

The condition for labor market clearing is that, in each state of the world,

$$
\sum_{i=1}^{m} l_{i}^{j}\left(s^{t}\right)=l^{j}\left(s^{t}\right)
$$

where $l^{j}\left(s^{t}\right)$ is total domestic labor supply given $s^{t}$. 


\section{Shock Processes}

To facilitate comparisons with previous research, we take stochastic productivity shocks to be country specific_as in the majority of IRBC models (notwithstanding Backus, Kehoe, and Kydland 1992; Baxter and Crucini 1995; Kollmann 1996; and Kehoe and Perri 2002). However, sectors within a country differ in terms of their respective elasticities (or loading factors) $z^{j}\left(s^{t}\right)$ with respect to the aggregate shocks: $A_{i}^{j}\left(s^{t}\right)=\exp \left(\eta_{i} z^{j}\left(s^{t}\right)\right)$. We suppose (as in the literature) that the two countries' technology shocks, $\mathbf{z}\left(s^{t}\right)=\left\{z^{H}\left(s^{t}\right), z^{F}\left(s^{t}\right)\right\}$, follow a vector autoregressive (VAR) process of the form

$$
\left(\begin{array}{c}
z^{H}\left(s^{t}\right) \\
z^{F}\left(s^{t}\right)
\end{array}\right)=\left(\begin{array}{cc}
\rho_{z} & 0 \\
0 & \rho_{z}
\end{array}\right)\left(\begin{array}{c}
z^{H}\left(s^{t-1}\right) \\
z^{F}\left(s^{t-1}\right)
\end{array}\right)+\left(\begin{array}{c}
\varepsilon_{z}^{H}\left(s^{t}\right) \\
\varepsilon_{z}^{F}\left(s^{t}\right)
\end{array}\right) .
$$

Here the innovations $\varepsilon_{z}=\left(\varepsilon_{z}^{H}, \varepsilon_{z}^{F}\right)$ are multivariate normal, independent, and identically distributed (i.i.d.) random variables with the same standard deviation $\sigma_{z}$ and with contemporaneous correlation $\operatorname{corr}\left(\varepsilon_{z}^{H}, \varepsilon_{z}^{F}\right) \cdot 11$

The country-specific preference shock is assumed to follow a first-order autoregressive or $\mathrm{AR}(1)$ process:

$$
\lambda^{j}\left(s^{t}\right)=\rho_{\lambda} \lambda^{j}\left(s^{t-1}\right)+\varepsilon_{\lambda}^{j}\left(s^{t}\right), \quad j=H, F,
$$

where $\varepsilon_{\lambda, t}^{j}$ is an i.i.d., zero-mean, normal process with standard deviation $\sigma_{\lambda}$ and where $\operatorname{corr}\left(\varepsilon_{\lambda}^{H}\left(s^{t}\right), \varepsilon_{\lambda}^{F}\left(s^{t}\right)\right)=0$.

\section{Quantitative Assessment}

In this section, we examine how the inclusion of factor proportions trade changes the properties of the international business cycle. We estimate a two-good "bond economy" model, in which there are shocks to both demand and productivity, and compare the results with a one-sector model. Our strategy is first to estimate the parameters of a home economy to match domestic moments and then to see whether the implied international moments match up well with the data. Table 2 (in Section B) reports the quantitative properties of the benchmark model and compares its results with the data as well as with results from a model with homogeneous sectors and other variants. The main result is that our two-sector model predicts positive international investment co-movement and, in turn, output co-movement. Furthermore, sectoral statistics match the data fairly well.

\footnotetext{
${ }^{11}$ This specification of technology processes is equivalent to assuming that $\log \left(A_{i}^{j}\left(s^{t}\right)\right)=\rho_{z} \log \left(A_{i}^{j}\left(s^{t-1}\right)\right)$ $+\eta_{i} \varepsilon^{j}\left(s^{t}\right)$.
} 


\section{A. Model Estimation}

The model is estimated with annual data because sectoral statistics are available only at a yearly frequency. The discount rate $\beta$ is set to 0.95 , which implies that the annual steady-state real interest rate is 5 percent. The risk aversion parameter $\sigma$ is set at 2 and the depreciation rate at 0.1 . We set $\psi$ to 2.44 , which corresponds to a (Frisch) elasticity of labor supply equal to 0.69 (as estimated in Pistaferri 2003) when preferences are as specified by GHH.

To compute sectoral shares and their associated factor intensities, we employ annual industry data (compensation paid to employees, value-added, net operating surplus) provided by the US Bureau of Economic Analysis (BEA). Sectoral labor shares (labor intensity) are calculated using the average of the three measures constructed in Section IIIA, a procedure that adjusts for self-employment and proprietors' income. The capital share, $\alpha_{i}$, is then calculated as 1 minus the labor share in each sector $i$. In aggregating all disaggregated sectors into two large sectors, we rank the sectors according to their labor shares in nominal value-added; we then categorize the highest-ranked half as labor intensive and the other sectors as capital intensive. In our model, the labor-intensive sector's share in value-added is $\gamma_{l}=\sum_{i=1}^{N / 2} \gamma_{i}=0.56$ (as in the data) and the capital-intensive sector's share is $\gamma_{k}=1-\gamma_{l}=0.44$. The factor shares of these two sectors-that is, $\alpha_{l}$ and $\alpha_{k}$-are computed as the weighted average of the capital share of each individual sector: $\alpha_{l}=\sum_{i=1}^{N / 2}\left(\gamma_{i} \alpha_{i} / \gamma_{l}\right)=0.16$ and $\alpha_{k}=\sum_{i>N / 2}^{N}\left(\gamma_{i} \alpha_{i} / \gamma_{k}\right)=0.59 .12$

Since the cross-country spillover parameter is set to 0 , productivities in domestic and foreign economies can be stochastically related only through the cross-country correlation of shocks: $\rho\left(\varepsilon_{z}^{H}, \varepsilon_{z}^{F}\right)$. For the purposes of comparing our results with previous work and of isolating our mechanism's contribution from the spillover effects of shock processes, we take Kehoe and Perri's (2002) parameter values as a benchmark and set $\operatorname{corr}\left(\varepsilon_{z}^{H}, \varepsilon_{z}^{F}\right)=0.25$. The set of fixed parameter values are summarized in panel A of Table 1.

We normalize the elasticity of productivity to aggregate shocks in capital-intensive sectors by putting $\eta_{k}=1$. The set of parameters to be estimated are given by $\left(\nu, \theta, \eta_{l}, b_{k}, b_{l}, \rho_{z}, \sigma_{z}, \rho_{\lambda}, \sigma_{\lambda}\right)$. Each of these estimated parameters is described in panel B of Table 1 .

The model is log-linearized around a symmetric steady state. Bayesian methods are used to fit the linearized model to four annual US time series: two sectoral observations, the real value-added in capital-intensive sectors $\left(Y_{k}\right)$ and the real value-added in labor-intensive sectors $\left(Y_{l}\right)$; and two aggregate observations, consumption and investment. ${ }^{13}$ The model's four corresponding shocks are the Home and Foreign preference shock and productivity shock. Despite the limited

\footnotetext{
${ }^{12}$ When factor shares are not adjusted for self-employment, the corresponding values are 0.24 and 0.63 . Simulations based on these alternative values show similar quantitative results.

${ }^{13}$ Bayesian methods have two main advantages over calibration methods. First, the former use general equilibrium conditions-rather than partial equilibrium models or reduced-form equations, which improves identification. Second, Bayesian methods perform better than do "generalized method of moments" methods for estimations based on small samples.
} 
TABLE 1 -PARAmeter VAlues

\begin{tabular}{lccc}
\hline \hline $\begin{array}{l}\text { Panel A. Calibrated parameters } \\
\text { Parameter }\end{array}$ & Value & Parameter & Value \\
\hline$\beta$ & 0.95 & $\sigma$ & 2 \\
$\kappa$ & 2.75 & $\psi$ & 2.44 \\
$\delta$ & 0.1 & $\gamma_{l}$ & 0.56 \\
$\alpha_{l}$ & 0.16 & $\alpha_{k}$ & 0.59 \\
$\operatorname{corr}\left(\varepsilon_{z}^{H}, \varepsilon_{z}^{F}\right)$ & 0.25 & $\eta_{k}$ & 1 \\
Panel B. Estimated parameters & & & \\
Parameter & & & \\
\hline$\nu$ & Value & $\mathrm{SD}$ & {$[5$ th, 95 th $]$} \\
$\theta$ & 0.735 & 0.095 & {$[0.613,0.904]$} \\
$b_{k}$ & 0.517 & 0.086 & {$[0.499,0.755]$} \\
$b_{l}$ & 0.114 & 0.034 & {$[0.075,0.191]$} \\
$\rho_{z}$ & 0.632 & 0.242 & {$[0.156,0.524]$} \\
$\sigma_{z}$ & 0.590 & 0.079 & {$[0.471,0.727]$} \\
$\eta_{l}$ & 0.014 & 0.002 & {$[0.012,0.016]$} \\
$\rho_{\lambda}$ & 1.673 & 0.117 & {$[1.526,1.772]$} \\
$\sigma_{\lambda}$ & 0.460 & 0.076 & {$[0.373,0.571]$} \\
\hline
\end{tabular}

Notes: The parameter $\beta$ denotes the discount factor, and $\sigma$ is the risk aversion parameter in the preference function. The term $\kappa$ governs the disutility of labor in the utility function, and $\psi$ captures the elasticity of labor supply; $\delta$ is the capital depreciation rate. The factor intensities $\alpha_{l}$ and $\alpha_{k}$ represent the share of labor in the labor-intensive sector and capital-intensive sector, respectively. The weight of the labor-intensive sector in the economy is denoted $\gamma_{l}$. The elasticity of productivity in sector $i$ with respect to aggregate productivity is given by $\eta_{i}$ for $i=k, l$, and $\rho\left(\varepsilon^{H}, \varepsilon^{F}\right)$ signifies the correlation between Home and Foreign productivity shocks. Other terms include: $\nu$, which governs the persistence of consumption habit formation; $\theta$, the elasticity of substitution between capital-intensive and labor-intensive inputs in final goods; $b_{i}$, the adjustment costs in sector $i(i=k, l) ; \rho_{z}$, the persistence parameter in the technology shock process; and $\sigma_{z}$, the standard deviation of shocks to technology. Finally, $\rho_{\lambda}$ and $\sigma_{\lambda}$ are (respectively) the preference shock's persistence parameter and standard deviation.

availability of sectoral observables, our sample spans the period from 1977 to 2013 inclusive. Appendix $\mathrm{C}$ describes in more detail the data and the distribution of our estimation's priors. In Table 1, panel B reports our model's estimated parameter values. The parameter $\nu$ is estimated to be 0.735 , which allows for a significant wealth effect on labor supply. The estimated elasticity of substitution between capital- and labor-intensive goods $(\theta)$ is 0.517 , and the estimated adjustment cost in the capital-intensive sector is smaller than its counterpart in the labor-intensive sector-in line with results reported by Samaniego and Sun (2015). The persistence parameter of technology shocks is estimated to be 0.59 , which implies a quarterly persistence of about 0.87; that is close to the value used in the workhorse model of Backus, Kehoe, and Kydland (1994). The estimated elasticity of shocks to the labor-intensive sector with respect to the aggregate shock (1.67) implies that the labor-intensive sector is about 70 percent more responsive to aggregate shocks than is the capital-intensive sector. From this it follows that the labor-intensive sector experiences a disproportionate expansion during booms and a disproportionate contraction during recessions, an outcome that is illustrated in Figure 1. Our estimated 
preference shock has a standard deviation of $\sigma_{\lambda}=2.8$, which is in line with values estimated in the literature. ${ }^{14}$

\section{B. Model Results}

Table 2 reports our simulation results for the various cases under consideration. All reported own-economy aggregate statistics are computed from US annual time series over the period 1970-2013. The sectoral statistics are likewise computed from US sectoral data but for a shorter period of time (1977-2013). International correlations refer to the average correlation between a US variable and its value in one of 16 countries belonging to the Organization for Economic Co-operation and Development (OECD): Australia, Austria, Canada, Denmark, Finland, France, Germany, Ireland, Italy, Japan, Korea, the Netherlands, Norway, Spain, Sweden, and the United Kingdom.

Impulse Responses. - To provide intuition for the key mechanism at hand, we first examine the model's impulse responses to a Home productivity shock (see Figure 4 and Figure 5). The technology shock is plotted in the lower right panel of Figure 4, which shows that it rises by about 1 percent and then slowly reverts to its mean. The increase in Home's aggregate productivity hits the labor-intensive sector disproportionately, causing the share of its employment and production in aggregate employment and production to rise and, conversely, the capital-intensive sector's share of employment and production to fall. However, the absolute levels of output and employment rise for both sectors (not pictured owing to space considerations). The increase in the world supply of labor-intensive goods pushes their relative price down while pushing up the relative prices of capital-intensive goods (lower left panel). In response to that increase, Foreign shifts resources toward the capital-intensive sector. Overall, Home (Foreign) becomes a net exporter of the labor-intensive (capital-intensive) intermediate good. An aggregate technology shock in one country therefore induces compositional changes both domestically and internationally.

A net inflow of investment from Home to Foreign, when combined with Foreign shifting its resources toward the capital-intensive sector, substantially increases the output of such goods in Foreign. Foreign GDP also rises, in stark contrast to the predicted fall in the standard one-sector case. Thus, the main difference in these models is that investment and output tend to rise in both economies in the two-sector case but tend to move in opposite directions in the one-sector case. Recall that, in the current calibration, the correlation of shocks across countries is positive and equal to 0.25 - per the value that is typically used in the literature. Whereas in standard models a positive correlation near this value is insufficient to generate positive co-movement, in our model that value results in the emergence of both investment

\footnotetext{
${ }^{14}$ Different models assume different combinations of shocks and consider different market structures and frictions. For example, the unanticipated preference shocks estimated by Schmitt-Grohé and Uribe (2012) have a standard deviation of 2.83. In Justiniano, Primiceri, and Tambalotti (2011), the standard deviation is 3.6; Campolmi and Gnocchi (2016) report a value of 1.47; and Christiano, Motto, and Rostagno (2014) find a value of 2.33 .
} 
Table 2-Simulated RBC Moments of the Model Compared with Data

\begin{tabular}{|c|c|c|c|c|c|c|c|}
\hline Moments & $\begin{array}{c}\text { Data } \\
(1)\end{array}$ & $\begin{array}{c}\text { Benchmark } \\
\text { (2) }\end{array}$ & $\begin{array}{c}\begin{array}{c}\text { Income } \\
\text { effect }\end{array} \\
(\nu=0.001) \\
(3)\end{array}$ & $\begin{array}{l}\text { Adjustment } \\
\text { costs } \\
\left(b_{k}=b_{l}\right) \\
\text { (4) }\end{array}$ & $\begin{array}{l}\text { Elasticity of } \\
\text { substitution } \\
(\theta=1) \\
(5)\end{array}$ & $\begin{array}{c}\text { No } \\
\text { preference } \\
\text { shock } \\
\left(\sigma_{\lambda}=0\right) \\
(6)\end{array}$ & $\begin{array}{c}\text { Homo- } \\
\text { geneous } \\
\text { sectors } \\
(7)\end{array}$ \\
\hline \multicolumn{8}{|c|}{ Panel A. Aggregate statistics } \\
\hline \multicolumn{8}{|c|}{ Volatility } \\
\hline$\sigma\left(y^{H}\right)$ & 2.24 & 2.45 & 2.83 & 2.46 & 2.37 & 2.45 & 2.39 \\
\hline$\sigma\left(t b y^{H}\right)$ & 0.62 & 0.71 & 0.53 & 0.78 & 0.67 & 0.30 & 1.18 \\
\hline$\sigma\left(c^{H}\right) / \sigma\left(y^{H}\right)$ & 0.83 & 0.55 & 0.59 & 0.54 & 0.55 & 0.38 & 0.53 \\
\hline$\sigma\left(i^{H}\right) / \sigma\left(y^{H}\right)$ & 3.19 & 3.45 & 2.99 & 3.45 & 3.38 & 3.28 & 3.75 \\
\hline$\sigma\left(l^{H}\right) / \sigma\left(y^{H}\right)$ & 0.99 & 0.28 & 0.42 & 0.29 & 0.30 & 0.26 & 0.28 \\
\hline \multicolumn{8}{|c|}{ Domestic co-movement } \\
\hline $\operatorname{corr}\left(c^{H}, y^{H}\right)$ & 0.68 & 0.60 & 0.88 & 0.59 & 0.58 & 0.91 & 0.54 \\
\hline $\operatorname{corr}\left(i^{H}, y^{H}\right)$ & 0.87 & 0.94 & 0.95 & 0.93 & 0.94 & 0.98 & 0.82 \\
\hline $\operatorname{corr}\left(l^{H}, y^{H}\right)$ & 0.28 & 0.89 & 0.99 & 0.90 & 0.90 & 0.95 & 0.91 \\
\hline $\operatorname{corr}\left(t b y^{H}, y^{H}\right)$ & -0.56 & 0.22 & -0.05 & 0.26 & 0.10 & 0.41 & 0.11 \\
\hline \multicolumn{8}{|c|}{ International correlations } \\
\hline $\operatorname{corr}\left(y^{H}, y^{F}\right)$ & 0.52 & 0.32 & 0.31 & 0.30 & 0.32 & 0.31 & 0.19 \\
\hline $\operatorname{corr}\left(c^{H}, c^{F}\right)$ & 0.35 & 0.25 & 0.29 & 0.24 & 0.22 & 0.70 & 0.18 \\
\hline $\operatorname{corr}\left(i^{H}, i^{F}\right)$ & 0.33 & 0.38 & 0.23 & 0.40 & 0.27 & 0.33 & -0.07 \\
\hline $\operatorname{corr}\left(l^{H}, l^{F}\right)$ & 0.42 & -0.09 & 0.11 & -0.08 & -0.03 & -0.04 & 0.06 \\
\hline \multicolumn{8}{|c|}{ Panel B. Sectoral statistics } \\
\hline \multicolumn{8}{|c|}{ Volatility } \\
\hline$\sigma\left(y_{k}^{H}\right) / \sigma\left(y^{H}\right)$ & 0.58 & 0.75 & 0.73 & 0.70 & 0.70 & 0.75 & $\mathrm{~N} / \mathrm{A}$ \\
\hline$\sigma\left(y_{l}^{H}\right) / \sigma\left(y^{H}\right)$ & 1.75 & 1.24 & 1.24 & 1.25 & 1.36 & 1.24 & $\mathrm{~N} / \mathrm{A}$ \\
\hline$\sigma\left(P_{k} / P_{l}\right) / \sigma\left(y^{H}\right)$ & 0.91 & 0.65 & 0.63 & 0.63 & 0.52 & 0.64 & $\mathrm{~N} / \mathrm{A}$ \\
\hline \multicolumn{8}{|c|}{ Correlations with domestic output } \\
\hline $\operatorname{corr}\left(y_{k}^{H}, y^{H}\right)$ & 0.79 & 0.83 & 0.85 & 0.86 & 0.84 & 0.84 & $\mathrm{~N} / \mathrm{A}$ \\
\hline $\operatorname{corr}\left(y_{l}^{H}, y^{H}\right)$ & 0.96 & 0.98 & 0.98 & 0.98 & 0.98 & 0.98 & $\mathrm{~N} / \mathrm{A}$ \\
\hline $\operatorname{corr}\left(P_{k} / P_{l}, y^{H}\right)$ & 0.70 & 0.64 & 0.68 & 0.68 & 0.67 & 0.65 & $\mathrm{~N} / \mathrm{A}$ \\
\hline $\operatorname{corr}\left(s_{k}^{H}, y^{H}\right)$ & -0.82 & -0.67 & -0.70 & -0.74 & -0.73 & -0.67 & $\mathrm{~N} / \mathrm{A}$ \\
\hline
\end{tabular}

Notes: The statistics in column 1 are calculated from US annual time series, 1970-2013-except for international correlations, which are calculated using data from the United States and 16 OECD countries. The data statistics are based on logged (except for the ratio of net exports to GDP) and HP-filtered data with a smoothing parameter of 100. The model statistics are computed using simulated data (in logs and HP-filtered) from a 1,000-period simulation of the model economy. Parameters are taken from the benchmark case in Table 1. Columns 1-6 refer to the two-sector bond economy case; column 7 is for the case $\alpha_{1}=\alpha_{2}$.

and output co-movement across countries. To highlight the basic mechanism at work, one can shut off this positive correlation between Home and Foreign productivity shocks; the result is that Foreign output and investment still rise after a shock, suggesting that (in the simple case) no positive correlation between productivity shocks is required. This thought experiment is detailed in Appendix B.

In short, there are two forces that determine the fate of internationally traded resources in a two-sector economy. First is the standard resource allocation effect, whereby inputs are shifted toward the more productive economy (investment flows toward Home), leading both inputs and outputs to move in opposite directions for Home and Foreign. The second force is the domestic composition effect, which causes investment to flow toward the country whose production structure becomes 
Panel A. Home K-int employment share

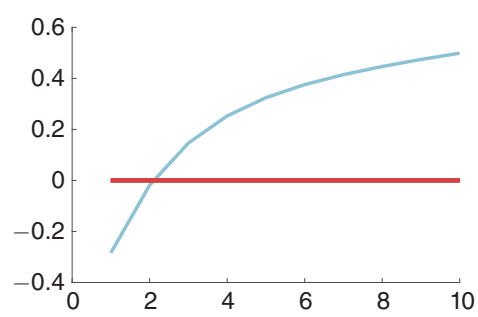

Panel C. Home K-int output share

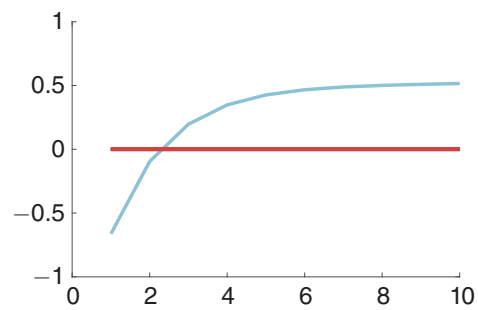

Panel E. K-int goods relative price $\left(P_{k} / P_{l}\right)$

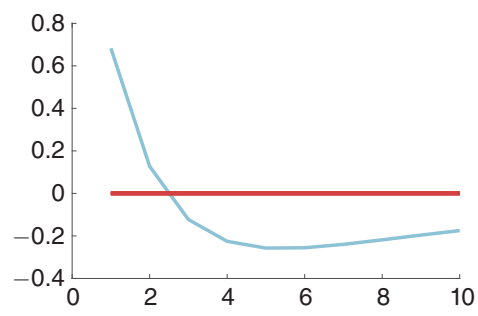

Panel B. Foreign K-int employment share

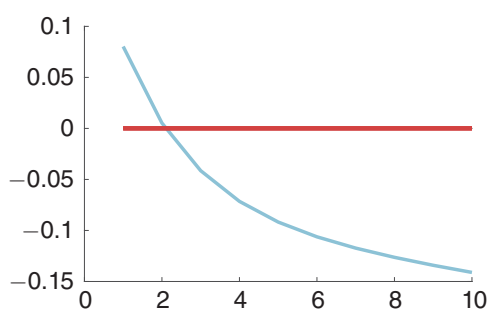

Panel D. Foreign K-int output share

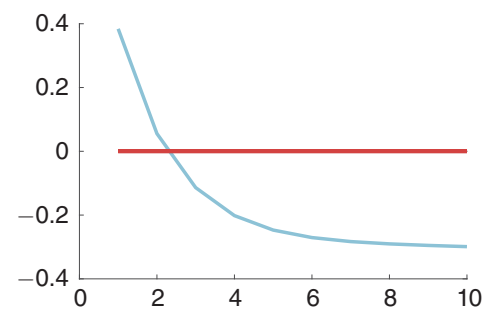

Panel F. Home productivity

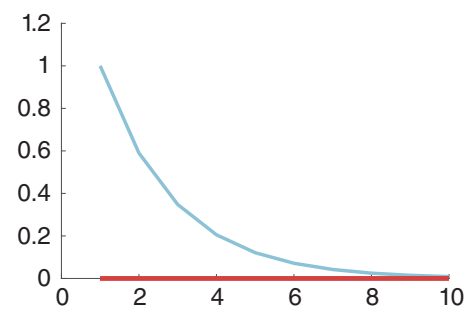

Figure 4. Home Productivity Shock-Sector-Level Variables

more capital intensive (here, Foreign). If the latter force (changes in composition) dominates the former (shifting of resources), then the net flow of investment resources is toward Foreign and aggregate investment rises in both countries.

Quantitative Results.-We now assess how well the model performs quantitatively at matching the data. Distinguishing sectors by factor intensity help explain cross-country co-movement in investment; this can be seen by comparing column 2 and column 7 of Table 2, where one parameter is changed at a time while the others remain at their benchmark values. Even though the model is estimated to target the domestic aggregate and sectoral observations, there is positive international investment co-movement $(0.38$, versus 0.33 in the data). In contrast, the correlation is negative when factor intensities are the same $(-0.07)$. Output is also positively correlated in the benchmark case $(0.32$, versus 0.52 in the data) and higher than when sectors are homogeneous (0.19) - a consequence of the now positive investment correlation. In the benchmark model, the international correlation 
Panel A. Home consumption

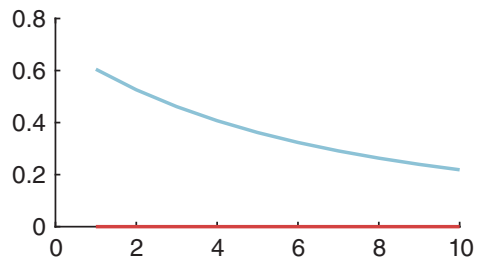

Panel C. Home investment

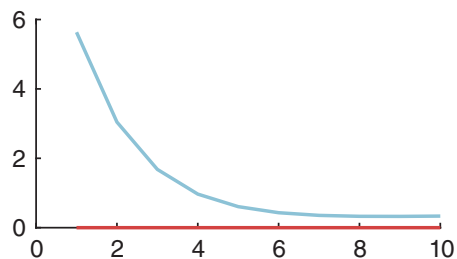

Panel E. Home output

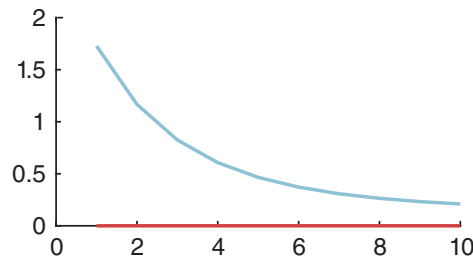

Panel G. Home net export

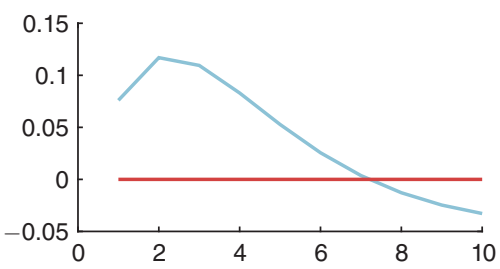

Panel B. Foreign consumption

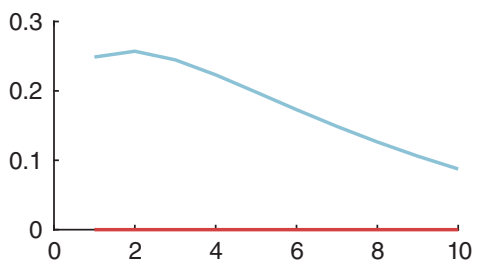

Panel D. Foreign investment

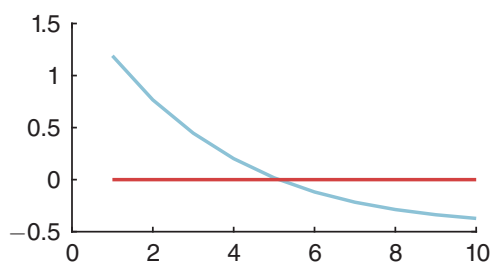

Panel F. Foreign output

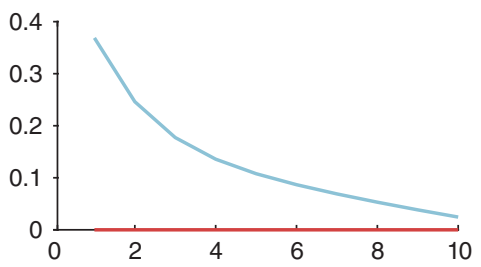

Panel $\mathrm{H}$. Home productivity

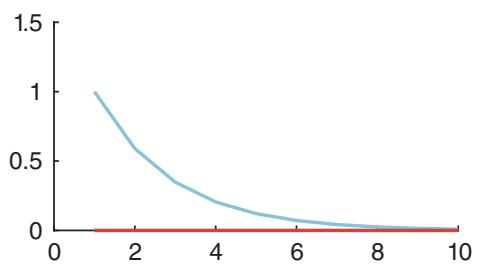

Figure 5. Home Productivity Shock-Economy-Wide Variables

of output ( 0.32 , versus 0.52 in the data) is greater than that of consumption across countries $(0.25$, versus 0.35 in the data).

The model's relative price of capital- to labor-intensive goods behaves broadly in line with the data in terms of its cyclicality, but is less volatile than in the data. The correlation of that relative price with de-trended GDP in the benchmark economy is 0.64 (versus 0.70 in the data), and its volatility as a fraction of the output volatility is 0.65 (versus 0.91 in the data). It helps our case that one does not need unreasonably large fluctuations in the relative price to generate aggregate co-movement in inputs and outputs across countries.

The sectoral statistics perform well when compared with the data. The correlation of capital-intensive output and domestic GDP is 0.83 in the benchmark economy (versus 0.79 in the data), and the correlation of labor-intensive output is 0.98 in the model (versus 0.96 in the data). The volatility of sectoral output also 
closely matches the data. Both in the data and in the model, real value-added in labor-intensive sectors is more volatile and also more procyclical. However, the model fails to replicate the data with regard to the procyclical trade balance and slightly negative labor co-movement that obtain under the benchmark economy. Because the parameter $\nu$ 's estimated value is 0.735 , our model generates a significant income effect of consumption on labor supply. As consumption rises in the Foreign economy in response to a Home productivity shock, the resulting strong income effect encourages Foreign to reduce its labor supply in order to offset the relative price effect on labor. In the table, column 3 shows that reducing the income effect (by setting $\nu$ close to zero and therefore preferences close to the GHH specification) can increase labor co-movement (0.11). Still, the mechanism we propose is not intended to explain positive labor co-movement, which occurs if the substitution effect dominates the income effect. Karabarbounis (2015) offers an example for the case when home production is added. ${ }^{15}$ Reducing the income effect can also generate a mild countercyclical trade deficit $(-0.05)$ due to stronger consumption and investment responses in the Foreign economy.

Our proposed mechanism, which leads to positive co-movement of both investment and output, relies on the heterogeneity of factor intensities across sectors and not on other types of heterogeneity. For example, in column 4, we assume equal adjustment costs across sectors while ensuring that the aggregate investment volatility remains comparable to that of the benchmark case. This change does not alter the international co-movement outcome.

Turning next to the effects of varying the elasticity of substitution, the benchmark model estimates the low value of $\theta=0.517$. Indeed, equation (12) implies that the lower elasticity of substitution between capital-intensive and labor-intensive goods helps generate larger relative price effects, and so could strengthen the mechanism. Yet, when we experiment with a higher level of substitution of $\theta=1$, the main results are unchanged (see column 5 of Table 2) - albeit with a weaker relative price movement, as reflected in a lower value for $\sigma\left(P_{k} / P_{l}\right)$. We therefore conclude that the key results do not depend on a low value of elasticity.

Finally, for the sake of comparability with existing literature, in column 6 of the table, we omit the demand shocks. It is clear that output and investment co-move positively across countries, although the consumption correlation becomes more positive over time than does the output correlation. Hence, demand shocks, which are country specific and therefore uncorrelated across countries, do not play a meaningful role in driving the co-movement of investment.

Overall, the mechanism described here is evidently robust to several large changes in the benchmark economy. We view this mechanism for endogenously generating investment co-movement as our model's main contribution. It provides an alternative explanation to those based on highly correlated shocks or on Kehoe and Perri's (2002) model of endogenously incomplete markets.

\footnotetext{
${ }^{15}$ In this scenario, Foreign labor can increase in response to a Home productivity increase because labor substitutes from nonmarket time to market time induced by the combination of higher wages, interest rates, and relative prices.
} 


\section{Sensitivity Analysis}

To show that the mechanism drawing international co-movement also operates under a variety of other shocks and settings, we conduct a sensitivity analysis based on altering the structure of shocks. ${ }^{16}$ We explore the cases of demand shocks affecting sectors differently and of productivity shocks affecting sectors symmetrically $\left(\eta_{1}=\eta_{2}\right)$. We also consider a setting in which there is an additional non-tradables sector. The stimation of model parameters for these different cases is detailed in Appendix C.

Taste Shocks.-We assume initially that preference shocks affect demand symmetrically in the two sectors. To capture the possibility of such shocks having an asymmetric impact across sectors, we augment the benchmark model with taste shocks $\tau_{i}^{j}\left(s^{t}\right)$, which enter the final goods aggregation as follows:

$$
\begin{aligned}
& c^{j}\left(s^{t}\right)=\left[\sum_{i=1}^{m} \gamma_{i}^{1 / \theta}\left(\tau_{i}^{j}\left(s^{t}\right) c_{i}^{j}\left(s^{t}\right)\right)^{(\theta-1) / \theta}\right]^{\theta /(\theta-1)}, \\
& I_{i}^{j}\left(s^{t}\right)=\left[\sum_{k=1}^{m} \gamma_{k}^{1 / \theta}\left(\tau_{k i}^{j}\left(s^{t}\right) z_{k i, t}^{j}\left(s^{t}\right)\right)^{(\theta-1) / \theta}\right]^{\theta /(\theta-1)} .
\end{aligned}
$$

Similarly to productivity shocks, the taste shocks incorporated into equations (16) and (17) follow $\tau_{i}^{j}\left(s^{t}\right)=\exp \left(\zeta_{i} d^{j}\left(s^{t}\right)\right)$. Here, $\zeta_{i}$ is the loading parameter (sensitivity) of sector $i$ to the country-specific taste shock $d^{j}\left(s^{t}\right)=\rho_{d} d^{j}\left(s^{t-1}\right)+\varepsilon_{d}^{j}\left(s^{t}\right)$, where $\varepsilon_{d}^{j}\left(s^{t}\right)$ is an i.i.d. zero-mean normal process. The standard deviation is $\sigma_{d}$, and there is no cross-country correlation: $\operatorname{corr}\left(\varepsilon_{d}^{H}, \varepsilon_{d}^{F}\right)=0$.

In the goods market, the market-clearing condition implies that the relative price of capital- to labor-intensive goods can now be expressed as

$$
\frac{p_{k t}}{p_{l t}}=\left[\frac{\gamma_{l}}{1-\gamma_{l}} \frac{D_{k t}^{j} D_{l t}^{j}}{{ }^{j}}\right]^{1 / \theta}\left(\frac{\tau_{k t}^{j}}{\tau_{l t}^{j}}\right)^{(\theta-1) / \theta},
$$

where $D_{i t}^{j}$ represents the demand of sector $i$ goods from country $j=H, F$. According to equation (18), if $\theta>1$, then a taste shock biased toward the labor-intensive sector can result in a countercyclical relative price of capital-intensive goods. In other words: when a taste shock affects the labor-intensive more than the capital-intensive sector, the relative price of capital-intensive goods can decline if $\theta>1$. This outcome fits the relative price pattern during 2002-2009 (as illustrated in Figure 3), which suggests that demand shocks might have been particularly important during that period.

\footnotetext{
${ }^{16}$ In each case, we reestimate the model using Bayesian methods and target (as in the benchmark case) the four time series.
} 
TABLe 3-Sensitivity Analysis

\begin{tabular}{|c|c|c|c|c|c|c|}
\hline \multirow[b]{2}{*}{ Moments } & \multirow{2}{*}{$\begin{array}{c}\text { Asymmetric } \\
\text { shocks } \\
(1)\end{array}$} & \multirow{2}{*}{$\begin{array}{c}\text { Asymmetric } \\
\text { taste } \\
(2)\end{array}$} & \multirow{2}{*}{$\begin{array}{c}\text { Symmetric } \\
\text { shocks } \\
(3)\end{array}$} & \multirow{2}{*}{$\begin{array}{c}\text { Idiosyncratic } \\
\text { productivity } \\
\text { (4) }\end{array}$} & \multicolumn{2}{|c|}{ Non-tradables } \\
\hline & & & & & $\begin{array}{c}\text { Data } \\
(5)\end{array}$ & $\begin{array}{c}\text { Model } \\
(6)\end{array}$ \\
\hline \multicolumn{7}{|c|}{ Panel A. Aggregate statistics } \\
\hline \multicolumn{7}{|c|}{ Volatility } \\
\hline$\sigma\left(y^{H}\right)$ & 2.67 & 4.09 & 3.91 & 2.28 & 2.24 & 3.09 \\
\hline$\sigma\left(t b y^{H}\right)$ & 0.52 & 0.55 & 0.77 & 0.72 & 0.62 & 1.44 \\
\hline$\sigma\left(c^{H}\right) / \sigma\left(y^{H}\right)$ & 0.52 & 0.40 & 0.41 & 0.54 & 0.83 & 0.43 \\
\hline$\sigma\left(i^{H}\right) / \sigma\left(y^{H}\right)$ & 3.60 & 3.30 & 3.70 & 3.07 & 3.19 & 4.02 \\
\hline$\sigma\left(l^{H}\right) / \sigma\left(y^{H}\right)$ & 0.41 & 0.37 & 0.07 & 0.28 & 0.99 & 0.50 \\
\hline \multicolumn{7}{|c|}{ Domestic co-movement } \\
\hline $\operatorname{corr}\left(i^{H}, y^{H}\right)$ & 0.96 & 0.98 & 0.96 & 0.87 & 0.87 & 0.84 \\
\hline $\operatorname{corr}\left(l^{H}, y^{H}\right)$ & 0.96 & 0.99 & 0.95 & 0.92 & 0.28 & 0.93 \\
\hline $\operatorname{corr}\left(t b y^{H}, y^{H}\right)$ & 0.25 & 0.45 & 0.23 & 0.20 & -0.56 & 0.27 \\
\hline \multicolumn{7}{|c|}{ International correlations } \\
\hline $\operatorname{corr}\left(y^{H}, y^{F}\right)$ & 0.15 & 0.22 & 0.19 & 0.21 & 0.52 & 0.28 \\
\hline $\operatorname{corr}\left(c^{H}, c^{F}\right)$ & 0.29 & 0.39 & 0.27 & 0.45 & 0.35 & 0.37 \\
\hline $\operatorname{corr}\left(i^{H}, i^{F}\right)$ & 0.33 & 0.29 & 0.22 & 0.06 & 0.33 & 0.25 \\
\hline $\operatorname{corr}\left(l^{H}, l^{F}\right)$ & -0.07 & 0.11 & 0.02 & -0.12 & 0.42 & 0.26 \\
\hline \multicolumn{7}{|c|}{ Panel B. Sectoral statistics } \\
\hline \multicolumn{7}{|c|}{ Volatility } \\
\hline$\sigma\left(y_{k}^{H}\right) / \sigma\left(y^{H}\right)$ & 0.60 & 0.85 & 0.94 & 0.92 & 1.25 & 0.92 \\
\hline$\sigma\left(y_{l}^{H}\right) / \sigma\left(y^{H}\right)$ & 1.29 & 1.09 & 1.11 & 1.30 & 2.39 & 1.72 \\
\hline$\sigma\left(P_{k} / P_{l}\right) / \sigma\left(y^{H}\right)$ & 0.53 & 0.29 & 0.31 & 0.71 & 2.06 & 1.59 \\
\hline \multicolumn{7}{|c|}{ Correlations with domestic output } \\
\hline $\operatorname{corr}\left(y_{k}^{H}, y^{H}\right)$ & 0.80 & 0.90 & 0.92 & 0.71 & 0.20 & 0.45 \\
\hline $\operatorname{corr}\left(y_{l}^{H}, y^{H}\right)$ & 0.94 & 0.98 & 0.97 & 0.94 & 0.91 & 0.98 \\
\hline $\operatorname{corr}\left(P_{k} / P_{l}, y^{H}\right)$ & 0.60 & 0.45 & 0.48 & 0.29 & 0.56 & 0.75 \\
\hline $\operatorname{corr}\left(s_{k}^{H}, y^{H}\right)$ & -0.80 & -0.54 & -0.48 & -0.47 & -0.54 & -0.58 \\
\hline
\end{tabular}

Notes: Column 1 corresponds to the case where $\tau_{i} \neq \tau_{j}$ and $\eta_{i} \neq \eta_{j}$; in this case, the loading factors on both productivity shocks and demand shocks are allowed to be symmetric across countries. Column 2 corresponds to the case where $\eta_{i}=\eta_{j}$ but $\tau_{i} \neq \tau_{j}$-that is, where productivity shocks are symmetric across sectors. Column 3 corresponds to the case where $\eta_{i}=\eta_{j}$ and $\tau_{i}=\tau_{j}$, and column 4 represents the case where the only shocks are idiosyncratic sectoral productivity shocks. Finally, columns 5 and 6 report the results when a non-tradables sector is added.

In addition, as shown in Table 3, incorporating asymmetric taste shocks does not alter our main result on international co-movement in output and investment-irrespective of whether there also exist productivity shocks that are asymmetric (column 1) or symmetric (column 2). The main difference is that, in the latter case, the Home and Foreign employment correlation (0.11) is positive only when taste shocks are asymmetric. The correlation between Home and Foreign consumption also becomes more positive after a taste shock, which means that the output-consumption correlation may have the opposite sign than in the benchmark model. When there are taste shocks, consumption correlations are higher than output correlations. 
Symmetric Shocks.-Column 3 of the table reports the results when productivity shocks are presumed to affect both sectors symmetrically (i.e., when $\eta_{k}=\eta_{l}$ ). In that case, the international co-movement is preserved. Under this estimation, the adjustment costs are estimated to be asymmetric; hence, labor-intensive sectors expand disproportionately more than capital-intensive sectors, in accordance with the pattern predicted by other models and confirmed in the data. Therefore, relative prices can still be procyclical when there are symmetric productivity shocks.

Idiosyncratic Productivity Shocks.-Our benchmark model assumes that total factor productivity (TFP) shocks are perfectly correlated across all sectors within the country. We now consider the case in which there are idiosyncratic, sector-specific TFP shocks in addition to the common shocks across sectors. Let $\ln \left(A_{i, t}^{j}\right)=\eta_{i} z_{t}^{j}+\xi_{i, t}^{j}$. Then the idiosyncratic component $\xi_{i, t}^{j}$ follows an $\mathrm{AR}(1)$ process and is not correlated across sectors and countries: $\xi_{i, t}^{j}=\rho_{\xi} \xi_{i, t-1}^{j}+\varepsilon_{\xi, t}^{j}$, where $\varepsilon_{\xi}^{j}\left(s^{t}\right)$ is an i.i.d. zero-mean normal process. Here, the standard deviation is $\sigma_{\xi}$, and $\operatorname{corr}\left(\varepsilon_{\xi}^{H}, \varepsilon_{\xi}^{F}\right)=0$.

As shown in column 4 of Table 3 , the positive investment correlations are now much weaker $(0.06)$ across countries, output correlation remains positive $(0.21)$, and international employment correlation is more negative $(-0.12)$. Since the shocks now have an idiosyncratic component, it follows that the within-country output and investment correlations are also much weaker.

Non-tradable Goods.-Non-tradable goods constitute much of an economy's output, so, next, we augment the existing framework by adding a domestic non-tradables sector in each country. Country $j$ 's production technology combines intermediate tradable goods $Y_{T}^{j}$ and non-tradable goods $Y_{N}^{j}$ to form a unit of the final good such that

$$
Y^{j}\left(s^{t}\right)=\left[\gamma_{T}^{1 / \zeta}\left(Y_{T}^{j}\left(s^{t}\right)\right)^{(\zeta-1) / \zeta}+\left(1-\gamma_{T}\right)^{1 / \zeta}\left(Y_{N}^{j}\left(s^{t}\right)\right)^{(\zeta-1) / \zeta}\right]^{\zeta /(\zeta-1)}
$$

here, $Y_{N}^{j}\left(s^{t}\right)$ and $Y_{T}^{j}\left(s^{t}\right)$ denote (respectively) country $j$ 's aggregate output of non-tradables and tradables given history $s^{t}$.

Let the gross output of the nontraded good in country $j$ be

$$
Y_{N}^{j}\left(s^{t}\right)=A_{N}^{j}\left(s^{t}\right)\left(K_{N}^{j}\left(s^{t}\right)\right)^{\alpha_{N}}\left(N_{N}^{j}\left(s^{t}\right)\right)^{1-\alpha_{N}}
$$

where $K_{N}^{j}\left(s^{t}\right)$ is the aggregate capital stock in the non-tradables sector, $N_{N}^{j}\left(s^{t}\right)$ is the labor used in the non-tradables sector in $j$ following $s^{t}$, and $\alpha_{N}$ is the share of capital in the non-tradable goods sector. The productivity shock to this sector is of the form $\log \left(A_{N t}^{j}\right)=\rho_{N} \log \left(A_{N, t-1}^{j}\right)+\varepsilon_{N, t}^{j}$, where $\varepsilon_{N, t}^{j}$ is an i.i.d. zero-mean 
normal process that has standard deviation $\sigma_{N}$ and is uncorrelated across countries: $\operatorname{corr}\left(\varepsilon_{N, t}^{H}, \varepsilon_{N, t}^{F}\right)=0$. Then, the overall consumer price index becomes

$$
P_{t}^{j}=\left[\gamma_{T}\left(P_{T, t}^{j}\right)^{1-\zeta}+\left(1-\gamma_{T}\right)\left(P_{N, t}^{j}\right)^{1-\zeta}\right]^{1 /(1-\zeta)},
$$

where $P_{T, t}^{j}$ is the same as equation (7) and is normalized to 1 . In equilibrium, both $p_{i t}$ and $P_{N, t}^{j}$ - the relative price of non-traded to traded goods in $j$ at $t$ - are determined endogenously. Investment in any tradables sector $i\left(x_{i}^{j}\left(s^{t}\right)\right)$ or in the non-tradables sector $N\left(x_{N}^{j}\left(s^{t}\right)\right)$ can be written as

$$
x_{u}^{j}\left(s^{t}\right)=\left[\sum_{k=1}^{m} \gamma_{i}^{1 / \theta}\left(z_{k i}^{j}\left(s^{t}\right)\right)^{(\theta-1) / \theta}\right]^{\theta /(\theta-1)} \quad \text { for } u=i, N .
$$

The additional market-clearing condition of the non-traded sector requires that the output of non-tradable goods in country $j$ be equal to the domestic consumption of that good:

$$
Y_{N, t}^{j}=C_{N, t}^{j} .
$$

The domestic labor market clears when $\sum_{i=1}^{m} N_{i t}^{j}+N_{N t}^{j}=N_{t}^{j}$.

Panel B of Table 3 compares the data moments with the model-generated moments. Since the data are now divided into three sectors, the sectoral statistics reported in column 5 of that panel differ from the data moments in column 1 of Table 2; however, the aggregate data moments are unchanged. These results establish that incorporating non-tradables sectors into the model does not alter our key results: the cross-country output and investment correlations are still positive, although the composition effects operating through the traded sectors is weakened (as reflected also in a lower $\operatorname{corr}\left(s_{k}^{H}, y^{H}\right)$ in both the data and the model). Meanwhile, cross-country labor input co-movement becomes positive with a correlation of 0.25 . The reason is that there is now a non-tradables sector that complements the tradables sector in production (cf. equation (19)). The volatilities of capital- and labor-intensive sectors in the case of three sectors are higher than in the two-sector case because, in the data, the non-tradables sector is much less volatile than the tradables sector (the standard deviation of de-trended real value-added of the non-tradables sector is about half that for the tradables sector). The volatility in the relative price of capital- and labor-intensive goods is also greater in the three-sector case, and the model-generated moment reflects this change well. We emphasize that the conditions for our key transmission mechanism are unchanged in the three-sector case. Namely, the labor-intensive sector is significantly more 
responsive to the business cycle, and the relative price of capital- and labor-intensive goods remains strongly procyclical in the data and also in the model. ${ }^{17}$

\section{Evidence Regarding the Transmission Mechanism}

In this section, we assess whether the key transmission mechanisms are consistent with evidence from the data; we also describe some new cyclical properties of sectoral data based on the distinction between capital and labor intensity in production. We start by conducting a consistency check to see whether sector-level TFP does indeed have a disproportionate effect on labor- versus capital-intensive sectors. ${ }^{18}$ Different from Figures 1 and 2 in which all industries are recast into two large sectors, the regression analyses here are performed at the most disaggregated industry level (so that we can use all the available information). We are interested in whether our model's prediction, that sectors respond differently to fluctuations in the business cycle, is borne out by the data. Undertaking a time-series analysis of sectoral responses to well-identified, country-specific shocks would not be feasible because the comparable sectoral data across countries are available for only a limited time period. We shall therefore focus on the correlations between sector-level variables and business cycles - that is, without attempting to establish causality.

\section{A. Data and Measurement}

Data Description.-Measures of productivity are from the 2012 release of the EU KLEM Growth and Productivity Accounts, which reports TFP growth (based on value-added) for 28 ISIC (International Standard Industrial Classification, Rev. 4) sectors at the most disaggregated level as well as aggregate TFP growth for 11 countries over the 1977-2010 period.

The data for sectoral production and prices in the United States come from two sources. The first is BEA's Industry Account dataset, which includes detailed annual industry production data (value-added, real value-added, employment, and wage compensation) for 61 private sectors at the most disaggregated level_corresponding to the North American Industrial Classification System (NAICS) two-four-digit level-for the period 1977-2013. Second, to show that results are not driven by particular sectors (e.g., services or construction), we check our core results using the NBER-CES Manufacturing Industry Database (2013), which provides manufacturing input and output data at the six-digit NAICS level for 1958-2005. Data at the highest level of disaggregation are used in order to maximize precision when

\footnotetext{
${ }^{17}$ Although not reported here (but available upon request), regression results indicate that the Backus-Smith (1993) correlations are also consistent with the data under this model. In a multi-sector setting, there is a strong and negative correlation between the real exchange rate and the consumption ratio $(-0.85$, versus -0.71 in data for the United States). We do not elaborate on this result because variation in the real exchange rate is in this case driven by fluctuations in the relative price of nontraded to traded goods - contrary to evidence that such variation is driven mostly by fluctuations in tradable goods. In this model, however, a positive productivity shock can lead to the real exchange rate appreciating in the domestic economy.

${ }^{18}$ But recall from Table 3's sensitivity analysis that this pattern is not crucial for our results if adjustment costs differ across sectors or if other shocks are allowed.
} 
classifying sectors according to their factor intensity. ${ }^{19}$ Sectoral price indices are constructed as the ratio of sectoral nominal value-added to real value-added. Highly disaggregated US trade data are provided by the US International Trade Commission (USITC). Trade value data are available at quarterly frequency for a rather limited period: 1989:I-1996:IV for four-digit SIC sectors and 1997:I-2011:IV for six-digit NAICS sectors.

Industry data for countries other than the United States are obtained from the OECD Structural Analysis (STAN) database, which publishes annual estimates of industry input and output at the ISIC two-four-digit level for 31 countries. Detailed industry data are available at different levels of disaggregation for different countries. We aggregate detailed industries in a way that yields 32 internationally comparable sectors at the two-three-digit ISIC level for each country. Compared with the US data, the cross-country data cover a far more limited time period. ${ }^{20}$

Measuring Sector-Specific Labor Intensity.-A commonly adopted measure of labor intensity is the share of employment compensation in nominal value-added (net operating surplus). The problem with this approach is that the proportion of income perceived by the self-employed as remuneration for their own work is recorded as capital income rather than labor income. We address this concern by considering two alternative measures. Data on proprietors' income and self-employment are available from the BEA; however, they are recorded at a much higher aggregated level. As an approximation, we assume that both the share of self-employment and the ratio of proprietor income to employment compensation do not differ across industries within the same sector. In the absence of further information on how to apportion proprietor income (since it includes both labor and capital income components), we construct the second measure by apportioning proprietor income equally to labor and capital and then adjusting the previous measure of capital share accordingly. The third measure assumes that self-employed workers would pay themselves the same wage that they could otherwise earn in the same industry; here the labor shares are adjusted by dividing them by the sectoral share of employees in total employment (cf. Gollin 2002). Because none of these measures is perfect, we take their average to obtain the final labor shares. ${ }^{21}$ The resulting estimates are then averaged across the sample period to obtain time-invariant labor shares. When NBER manufacturing data is used, we calculate the labor share of industry nominal value-added simply as total payroll divided by nominal value-added (since in this case no additional information on

\footnotetext{
${ }^{19}$ An important point emphasized by Schott (2003) is that greater disaggregation within the same industry can render input intensities more heterogeneous. Standard industry classifications group goods roughly according to end-use similarity (i.e., goods that are close substitutes rather than goods manufactured with similar factor inputs), "A procedure not necessarily consistent with the conceptualization of goods in the factor proportions framework" (Schott 2003). For this reason, one should always use the most disaggregated sectoral data when studying issues related to factor proportions.

${ }^{20}$ For instance, reliable industry data from the STAN database for 1991-2008 are available at only annual frequencies for Germany, France, Italy, and the United Kingdom.

21 The adjusted and unadjusted labor shares are highly correlated.
} 
self-employment or proprietor income is available). More detailed descriptions of the data and methodologies are provided in Appendix A. ${ }^{22}$

\section{B. Evidence on Asymmetric TFP Shocks across Sectors}

One may wonder whether empirical patterns of sectoral TFP are consistent with our estimation results from the benchmark model-namely, that aggregate TFP is more biased toward labor-intensive sectors. To test this, we examine whether the responses of sectoral TFP growth to aggregate TFP growth are positively associated with the sector's labor intensity. We obtain the following regression results:

$$
\Delta \ln T F P_{i c, t}=\underset{(2.48)}{0.002}+\underset{(4.31)}{0.678 \Delta \ln T F P_{c, t}}+\underset{(3.31)}{0.716 \Delta \ln T F P_{c, t}} \times S_{i}+f_{c i}+\varepsilon_{i c, t},
$$

where $T F P_{c, t}$ is the economy-wide TFP growth (based on real value-added) in country $c$, the term $S_{i}$ represents the time-invariant labor intensity in sector $i$, and $f_{c i}$ is the country-sector fixed effect; $t$-statistics are given in brackets. The coefficient for the interaction between aggregate TFP growth and labor intensity $\left(\Delta \ln T F P_{c, t} \times S_{i}\right)$ is positive and significant at the 95 percent confidence level. This empirical finding is consistent with the loading factor on TFP estimated being greater in the labor-intensive sector than the capital-intensive sector $\left(\eta_{l}>\eta_{k}\right)$ in our benchmark model.

\section{Domestic Composition Effects: Evidence Based on US Data}

Our theory predicts that during booms: (i) sectors with higher labor intensity tend to expand more (i.e., higher increases in output and input); (ii) the relative price of goods from sectors that use labor input more intensively falls more; and (iii) a sector's net exports are increasing in its labor intensity.

To examine these relationships systematically across all sectors, the following regression is performed using detailed sectoral data: ${ }^{23}$

$$
\Delta X_{i, t}=\beta_{0}+\beta_{1} \Delta \ln Y_{t}+\beta_{2} \Delta \ln Y_{t} \times S_{i}+f_{i}+\varepsilon_{i, t}
$$

Here, $\Delta X_{i, t}$ stands for the dependent variable of interest, which may be: (A) the growth rate of real value-added in sector $i$ in year $t$, denoted $\Delta \ln y_{i, t} ;$ (B) the growth rate of employment in sector $i$, or $\Delta \ln l_{i, t}$; (C) the growth rate of real investment in sector $i$, or $\Delta \ln i_{i, t}$; (D) the growth rate of the price index of output in sector $i$ relative to the consumer price index, $\Delta \ln p_{i, t}$; or $(\mathrm{E})$ the change in the ratio of net exports to GDP in sector $i$, or $\Delta n x_{i, t}$. The independent variables include: the economy-wide real GDP growth rate, $\Delta \ln Y_{t}$ (an indicator of business cycles); an interaction term between real GDP growth and the labor intensity in sector $i$, denoted $\Delta \ln Y_{t} \times S_{i}$; and industry fixed effects, $f_{i}$. Estimates of equation (23) are reported in Table 4, where

\footnotetext{
${ }^{22}$ We also compute factor shares using the STAN data on 36 industries. The ranking of sectors is strongly similar across countries.

${ }^{23}$ Including more lags in (23) results in no significant changes to our results; in most cases, the coefficients for lagged variables are not significant.
} 
TABle 4-Sectoral CyClicality and Labor INTENSITy

\begin{tabular}{|c|c|c|c|c|c|}
\hline $\begin{array}{l}\text { Dependent } \\
\text { variable: }\end{array}$ & $\begin{array}{c}\Delta \ln y_{i, t} \\
\text { (A) }\end{array}$ & $\begin{array}{c}\Delta \ln l_{i, t} \\
(\mathrm{~B})\end{array}$ & $\begin{array}{c}\Delta \ln i_{i, t} \\
(\mathrm{C})\end{array}$ & $\begin{array}{c}\Delta \ln p_{i, t} \\
\text { (D) }\end{array}$ & $\begin{array}{c}\Delta n x_{i, t} \\
(\mathrm{E})\end{array}$ \\
\hline \multicolumn{6}{|c|}{ Panel A. All sectors, SIC two-three digit } \\
\hline$\Delta \ln Y_{t}$ & $\begin{array}{l}-0.091 \\
(-0.18)\end{array}$ & $\begin{array}{c}-0.161 \\
(-0.32)\end{array}$ & $\begin{array}{l}1.116 \\
(1.51)\end{array}$ & $\begin{array}{l}1.404 \\
(3.63)\end{array}$ & - \\
\hline$\Delta \ln Y_{t} \times S_{i}$ & $\begin{array}{r}\mathbf{1 . 9 4 4} \\
(2.62)\end{array}$ & $\begin{array}{c}\mathbf{1 . 5 9 8} \\
(2.20)\end{array}$ & $\begin{array}{l}\mathbf{2 . 4 0 9} \\
(2.31)\end{array}$ & $\begin{array}{c}-2.001 \\
(-3.67)\end{array}$ & - \\
\hline Sector FEs & Yes & Yes & Yes & Yes & - \\
\hline Observations & 2,013 & 2,013 & 1,980 & 1,944 & - \\
\hline \multicolumn{6}{|c|}{ Panel B. Manufacturing, NAICS six-digit } \\
\hline$\Delta \ln Y_{t}$ & $\begin{array}{l}1.197 \\
(2.65)\end{array}$ & $\begin{array}{l}-0.079 \\
(-0.34)\end{array}$ & $\begin{array}{l}-1.198 \\
(-2.22)\end{array}$ & $\begin{array}{l}-0.188 \\
(-1.67)\end{array}$ & $\begin{array}{l}-1.565 \\
(-3.39)\end{array}$ \\
\hline$\Delta \ln Y_{t} \times S_{i}$ & $\begin{array}{l}\mathbf{2 . 1 8 7} \\
(2.27)\end{array}$ & $\begin{array}{r}\mathbf{2 . 9 9 7} \\
(5.26)\end{array}$ & $\begin{array}{r}\mathbf{8 . 9 0 3} \\
(7.21)\end{array}$ & $\begin{array}{c}-\mathbf{1 . 3 8 2} \\
(-2.65)\end{array}$ & $\begin{array}{l}\mathbf{3 . 0 7 4} \\
(2.85)\end{array}$ \\
\hline Sector FEs & Yes & Yes & Yes & Yes & Yes \\
\hline Observations & 21,330 & 21,802 & 21,802 & 21,330 & 21,253 \\
\hline
\end{tabular}

Notes: The dependent variable is the percentage change of real value-added in sector $i$ at time $t$ as a consequence of: the percentage change in employment (column A), the percentage change in real investment (column B), the percentage change in price (column C) and as normalized by the aggregate price index (column D), and the change in the ratio of net exports to GDP from the United States to EU15 economies (column E). Columns A-D report coefficient estimates based on two data sets each: the US industry account database, which provides sector-level production, price, and labor intensity data covering 61 two-three-digit SIC private sectors in the United States for 1977-2010; and the NBER-CES manufacturing dataset, which provides the same type of data for 428 six-digit NAICS manufacturing sectors for the period 1972-2005. Data for column E is from the USITC, which provides import-export data on 382 six-digit NAICS sectors for the period 1997:I-2011:I. Robust $t$-statistics are reported in parentheses.

columns A-E present results for, respectively, the dependent variables $(A)-(E)$ just described.

The domestic compositional and price effects should, in principle, apply to all sectors; that is why we report results using information for all available sectors. However, to show that these results are not driven by a specific set of sectors (e.g., non-tradables, services, construction), we also examine manufacturing sectors alone. Because manufacturing production data are available at more disaggregated levels (NAICS six-digit), our measures of factor intensity will be more precise (thereby addressing the concern expressed by Schott 2003). Moreover, manufacturing data allow for more observations (from years 1958-2005).

We are especially interested in the regression coefficient for the interaction term between the sector's factor intensity and US real GDP growth. In Table 4, panel A shows that the estimate of $\beta_{2}$ is positive and statistically significant; this implies that positive real GDP growth is associated, in the United States, with a greater increase (of real value-added) in sectors that are more labor-intensive. To illustrate the magnitude of these effects, consider two sectors: one whose labor intensity is 40 percent; the other, 85 percent (these values correspond roughly to the weighted average labor shares of our sample's bottom-half and top-half sectors). The left column of panel A suggests that a 1 percent rise in US GDP growth is associated with an increase of 0.7 percent in real value-added of the relatively capital-intensive 
sector yet with a much larger increase of 1.6 percent in the relatively labor-intensive sector.

Similarly, the estimates in panels B and C indicate that more labor-intensive sectors are associated with greater increases (decreases) in employment and investment during economic booms (recessions). The dependence of the differential responses of sector-level employment and investment on the sector's labor intensity is significant. In the previous example of two representative sectors, these estimates imply that employment in the representative capital-intensive sector increases by 0.5 percent after a 1 percent increase in GDP, while employment in the labor-intensive sector increases by 1.2 percent-more than double the response of the capital-intensive sector. Investment in the capital-intensive sector rises by 2.1 percent, compared with a 3.2 percent increase in the labor-intensive sector.

The estimates for $\beta_{2}$ in panel D are significant and negative, which means that a US boom is associated with greater declines in the prices of goods in sectors that are more labor-intensive. Turning again to the two large sectors in our previous example, the left column of this panel indicates that a 1 percentage point rise in US growth is associated with an 0.6 percentage point increase in the prices of products in the capital-intensive sector but with a 0.3 percentage point decline of those in the labor-intensive sector.

These differential sectoral responses to the business cycle are statistically significant not just economy-wide, but also among manufacturing sectors, although there the magnitude of the difference is smaller (see the right column of each panel in Table 4). Using a similar example (labor intensity correspond to 0.34 and 0.51 in the representative capital- and labor-intensive sector), the real value-added of an average labor-intensive manufacturing sector increases by 2.31 percent. In that labor-intensive sector, employment (investment) increases by 1.45 (3.38) percent in response to a 1 percent increase in real GDP growth-as compared with values of 1.94 percent in value added and 0.94 and 1.83 percent for employment and investment in the representative capital-intensive manufacturing sector. ${ }^{24}$ A related finding is that the normalized price of goods produced by the labor-intensive (capital-intensive) sector falls by $0.54(0.38)$ percent.

Another implication of the model that supports our international transmission mechanism is the behavior of net exports. While we know that the trade balance as a whole is countercyclical, a key prediction of our model is that the extent of cyclicality varies with labor intensity: the more labor intensive is a sector, the more procyclical is its net exports. These predictions are confirmed in panel E of Table 4. On average, the aggregate trade balance is indeed countercyclical $\left(\beta_{1}<0\right)$. The coefficient $\beta_{2}>0$, however, indicates that a sector's net exports tend to increase with its labor intensity. In fact, among the 382 tradables sectors in our dataset, less than a fourth of their net export levels respond positively to business cycle booms.

\footnotetext{
${ }^{24}$ Labor intensity in this case amounts to total payroll as a share of shipped value (where raw materials are viewed as inputs). Hence, the calculated labor share is much smaller: 0.14 for the capital-intensive sector and 0.25 for the labor-intensive sector.
} 


\section{International Transmission: Evidence Based on Cross-Country Data}

Domestic business cycles are associated not only with domestic but also foreign compositional changes and with a change in the international relative price of capitaland labor-intensive goods. Here, we examine whether our international transmission mechanism is reflected in other countries' compositional changes. Our model has two main implications. The first is that domestic booms are associated with a greater expansion in labor-intensive sectors, whereas a Foreign boom is associated with a domestic expansion in capital-intensive sectors. Second, the model implies that booms in either domestic or foreign economies are associated with a fall in the relative price of labor-intensive goods. We test the validity of these implied claims by examining the cyclical behavior of sectoral output and prices in response to domestic and foreign business cycles. For that purpose we run the following regression:

$$
\begin{aligned}
\Delta \ln X_{i c t}= & \beta_{0}+\left(\beta_{1}+\beta_{2} S_{i}\right) \Delta \ln Y_{c, t}+\left(\beta_{3}+\beta_{4} S_{i}\right) \Delta \ln Y_{-c, t} \\
& +\left(\beta_{5}+\beta_{6} S_{i}\right) \Delta \ln Y_{i t}+f_{i c}+\varepsilon_{i c t},
\end{aligned}
$$

where $\Delta X_{i c t}$ signifies either the growth rate of real value-added in sector $i$ of country $c$ in year $t$ (i.e., $\Delta \ln y_{i c t}$ ) or the price of sector- $i$ goods in country $c$ relative to the consumer price index in that country $\left(\Delta \ln p_{i c t}\right)$. We use $\Delta \ln Y_{c, t}$ and $\Delta \ln Y_{-c, t}$ to denote (respectively) the GDP growth rate in country $c$ and the average GDP growth rate for all other OECD countries (i.e., excluding $c$ ). We include $\Delta \ln Y_{i t}$, the average growth rate of real value-added across all countries in sector $i$, to control for worldwide but sector-specific shocks; $f_{i c}$ is the country-industry fixed effect.

Table 5 displays the regression results of equation (24). The table's second and third rows show how sectoral outputs and inputs (in columns 1-3) respond to domestic business cycles, and the fourth and fifth rows demonstrate how they respond to foreign business cycles. Interestingly, sectors expand by more, the more labor-intensive they are $\left(\beta_{2}>0\right)$ in response to domestic booms, while they contract more the more labor-intensive they are in response to foreign booms $\left(\beta_{4}<0\right)$. This finding accords with the international transmission mechanism, whereby a positive Home productivity shock leads to a disproportionate increase in the value-added from Foreign's capital-intensive sector but a decrease from Home's labor-intensive sector.

Column 4 of Table 5 shows that both domestic and foreign booms are associated with a decrease in the price of labor-intensive goods relative to capital-intensive goods $\left(\beta_{2}, \beta_{4}<0\right)$. Taken together, this evidence is consistent with the view that there is a transmission mechanism of business cycles that works by way of changes in the relative prices associated with composition effects. In particular, positive shocks abroad lead to an increase in the prices of capital-intensive goods, which motivates investment and capital inflow while stimulating domestic output and input. Through this channel, shocks are positively propagated across countries. 
Table 5-Cross-Country Observations (31 OECD countries, 1975-2010)

\begin{tabular}{lcccc}
\hline \hline & $\Delta \ln y_{i c t}$ & $\Delta \ln l_{i c t}$ & $\Delta \ln i_{i c t}$ & $\Delta \ln p_{i c t}$ \\
Dependent variable: & $(1)$ & $(2)$ & $(3)$ & $(4)$ \\
\hline$\Delta \ln Y_{c, t}$ & 0.649 & 0.321 & 1.628 & 0.396 \\
$\Delta \ln Y_{c, t} \times S_{i}$ & $(5.78)$ & $(3.06)$ & $(3.08)$ & $(2.95)$ \\
& $\mathbf{0 . 6 0 7}$ & $\mathbf{0 . 3 3 5}$ & $\mathbf{0 . 8 0 8}$ & $-\mathbf{0 . 2 1 6}$ \\
$\Delta \ln Y_{-c, t}$ & $(3.92)$ & $(2.43)$ & $(1.13)$ & $(-1.16)$ \\
$\Delta \ln Y_{-c, t} \times S_{i}$ & -0.560 & 0.234 & 1.515 & 1.384 \\
$\Delta \ln Y_{i, t}$ & $(-3.28)$ & $(1.63)$ & $(1.98)$ & $(6.42)$ \\
$\Delta \ln Y_{i, t} \times S_{i}$ & $-\mathbf{0 . 6 5 2}$ & $-\mathbf{0 . 8 2 8}$ & $-\mathbf{2 . 3 6 9}$ & $-\mathbf{1 . 4 6 5}$ \\
Country-sector FEs & $(-2.54)$ & $(-4.24)$ & $(-2.21)$ & $(-4.83)$ \\
Observations & 0.537 & -0.170 & -1.322 & -1.076 \\
& $(6.82)$ & $(-3.01)$ & $(-4.26)$ & $(-11.28)$ \\
& 0.628 & 0.613 & 2.736 & 0.909 \\
Notes: The first & $(5.77)$ & $(7.92)$ & $(0.22)$ & $(6.88)$ \\
& Yes & Yes & Yes & Yes \\
& 19,696 & 10,683 & 14,742 & 15,888 \\
\hline
\end{tabular}

Notes: The first three data columns report coefficients for a regression in which the dependent variable is the percentage change in real value-added (column 1), the percentage change in employment (column 2), or the percentage change in investment in sector $i$ of country $c$ at time $t$ (column 3). In column 4, the dependent variable is the percentage change in price as normalized by the aggregate price index. Labor intensity is measured as the share of labor cost in value-added (minus net operating profit and taxes, less subsidies). Our source for data is the OECD STAN database for 31 OECD countries and 32 sectors over the period 1975-2010 — although for many countries the only available observations are from year 1992. Robust $t$-statistics are reported in parentheses.

\section{Conclusion}

This paper incorporates differences in factor proportions across sectors into a two-country model of stochastic growth. Endogenous domestic and foreign composition effects, brought about by international trade, lead to a positive transmission of country-specific productivity shocks across countries that-under conditions met by the data-can more than offset the negative transmission of shocks (via resource shifting across countries) that underlies standard models. The new transmission mechanism that we describe occurs through changes in the relative price of capital- and labor-intensive goods, and we provide empirical support for the key elements of this process.

In investigating business cycles, this paper exploits our potentially illuminating separation of labor-intensive sectors from capital-intensive sectors. Composition changes is not only a long-run phenomenon but also an empirical regularity at the business cycle frequency. Our new empirical findings on the distinctive behavior of capital- and labor-intensive industries may serve as a starting point for more thorough theoretical and empirical investigations into the nature of sectors characterized by different factor intensities - in the contexts of domestic and international business cycles. 


\section{APPENDiX A: DATA}

Sectoral Statistics of Production.-The sectoral evidence of employment and real value-added for the United States is based on data obtained from the BEA Industry Account dataset, which provides annual series of nominal/real (chain-type, base year 2005) value-added, price index, and components of value-added at the NAICS two-four-digit level from 1977 to 2013. There are 61 private sectors at the most disaggregated level, among which 38 are classified as tradables sectors according to Stockman and Tesar's (1995) definition. ${ }^{25}$ We use all private sectors in most of our empirical tests but also confirm that our sectoral evidence does not vary significantly when we limit our sectors to tradables only.

Capital share in value-added is calculated as 1 minus labor share in the corresponding sector. There are three methods to construct sectoral labor shares. First, following the standard assumption of a Cobb-Douglas production function and competitive markets, the time-average labor share $\left(l s_{1}\right)$ at the detailed industry level is constructed as $l s_{1}=\frac{1}{T} \sum_{t=1}^{T} l s_{t}$, where $l s$ is defined as the compensation of employees divided by the difference between value-added and taxes (less subsidies). In this approach, the proportion of income perceived by the self-employed as remuneration for their own work is recorded as capital income rather than labor income. To adjust for this problem, we consider two alternative measures. The BEA provide data on proprietors' income and self-employment, but they are recorded at a more aggregated level (NAICS two-digit). As an approximation, we assume industries within the same category have the same proprietors' income to employment compensation ratios and also the same share of self-employment. Owing to a lack of further information on how to apportion proprietor income (as it includes both labor and capital income components), we construct the second measure by apportioning proprietor income equally to labor and capital and then adjusting the previous measure of capital share accordingly. That is,

$$
l s_{2}=1-\frac{\frac{1}{2}(\text { Employees' compensation }+ \text { Proprietors' income })}{\text { Value-added }- \text { Taxes less subsidies }} .
$$

To obtain the third measure, we assume that self-employed workers would pay themselves the same wage that they could otherwise earn in the same industry. Thus,

$$
l s_{3}=l s_{1} \times \frac{\text { Full-time equivalent employment }+ \text { Self-employment }}{\text { Self-employment }} .
$$

The average of these three measures, $\left(l s_{1}+l s_{2}+l s_{3}\right) / 3$, is then used as our final measure of labor shares. Table A1 lists the 61 private sectors in descending order of their computed labor share in nominal value-added.

\footnotetext{
${ }^{25}$ This includes agriculture, manufacturing, mining, wholesale and retail trade, and transportation.
} 
Table A1-Sectoral Labor Share in the United States

\begin{tabular}{|c|c|}
\hline Industry & Labor share \\
\hline Educational services & 0.919 \\
\hline Hospitals and nursing and residential care facilities & 0.915 \\
\hline Computer systems design and related services & 0.907 \\
\hline Management of companies and enterprises & 0.903 \\
\hline Food services and drinking places & 0.902 \\
\hline Computer and electronic products & 0.900 \\
\hline Securities, commodity contracts, and investments & 0.886 \\
\hline Printing and related support activities & 0.876 \\
\hline Ambulatory health care services & 0.873 \\
\hline Other transportation equipment & 0.854 \\
\hline Wood products & 0.849 \\
\hline Furniture and related products & 0.848 \\
\hline Wholesale trade & 0.846 \\
\hline Construction & 0.840 \\
\hline Other transportation and support activities & 0.839 \\
\hline Retail trade & 0.838 \\
\hline Motor vehicles, bodies and trailers, and parts & 0.829 \\
\hline Social assistance & 0.825 \\
\hline Other services, except government & 0.819 \\
\hline Miscellaneous professional, scientific, and technical services & 0.810 \\
\hline Textile mills and textile product mills & 0.809 \\
\hline Accommodation & 0.809 \\
\hline Warehousing and storage & 0.804 \\
\hline Amusements, gambling, and recreation industries & 0.796 \\
\hline Air transportation & 0.791 \\
\hline Machinery & 0.786 \\
\hline Fabricated metal products & 0.779 \\
\hline Apparel and leather and allied products & 0.766 \\
\hline Administrative and support services & 0.764 \\
\hline Information and data processing services & 0.763 \\
\hline Performing arts, spectator sports, museums, and related activities & 0.761 \\
\hline Waste management and remediation services & 0.761 \\
\hline Truck transportation & 0.759 \\
\hline Transit and ground passenger transportation & 0.750 \\
\hline Rail transportation & 0.745 \\
\hline Plastics and rubber products & 0.744 \\
\hline Primary metals & 0.742 \\
\hline Nonmetallic mineral products & 0.732 \\
\hline Miscellaneous manufacturing & 0.730 \\
\hline Publishing industries (includes software) & 0.722 \\
\hline Insurance carriers and related activities & 0.717 \\
\hline Support activities for mining & 0.711 \\
\hline Electrical equipment, appliances, and components & 0.695 \\
\hline Legal services & 0.677 \\
\hline Paper products & 0.660 \\
\hline Funds, trusts, and other financial vehicles & 0.615 \\
\hline Forestry, fishing, and related activities & 0.615 \\
\hline Motion picture and sound recording industries & 0.610 \\
\hline Food and beverage and tobacco products & 0.600 \\
\hline Water transportation & 0.596 \\
\hline Mining, except oil and gas & 0.584 \\
\hline Chemical products & 0.535 \\
\hline Pipeline transportation & 0.530 \\
\hline Federal Reserve banks, credit intermediation, and related activities & 0.524 \\
\hline Broadcasting and telecommunications & 0.485 \\
\hline Utilities & 0.374 \\
\hline Farms & 0.278 \\
\hline Oil and gas extraction & 0.268 \\
\hline Petroleum and coal products & 0.241 \\
\hline Rental and leasing services and lessors of intangible assets & 0.233 \\
\hline Real estate & 0.071 \\
\hline
\end{tabular}


All sectors are then regrouped into one of two larger sectors: the labor-intensive sector if its capital share is lower than the median and the capital-intensive sector otherwise. Both real and nominal value-added, as well as the number of employees, are summed up in the two sectors. Price indices for the labor-intensive and capital-intensive sectors are then calculated by dividing the aggregated nominal value-added over the aggregated real value-added.

It is important to note that sectoral and aggregate quantities published by the BEA are all based on the Fisher quantity (chained) index $\left(Q_{t}^{F}\right)$, which is the geometric mean of the Laspeyres quantity index $\left(Q_{t}^{L}\right)$ and the Paasche quantity index $\left(Q_{t}^{P}\right)$ :

$$
Q_{t}^{F}=\left(Q_{t}^{L} Q_{t}^{P}\right)^{1 / 2}, \quad Q_{t}^{L}=\frac{\sum_{i}^{N} p_{i t-1} q_{i t}}{\sum_{i}^{N} p_{i t-1} q_{i t-1}}, \quad Q_{t}^{P}=\frac{\sum_{i}^{N} p_{i t} q_{i t}}{\sum_{i}^{N} p_{i t} q_{i t-1}}
$$

here $p_{i t}$ and $q_{i t}$ are the price and quantity of good $i$ at time $t$. Therefore, GDP components in chained prices are not additive. Hence, we must first construct industry real value-added in terms of constant prices in order to calculate the real quantities at a more aggregated level in both sectors. It is easy to show that the growth rate of GDP in chained prices can be decomposed as ${ }^{26}$

$$
\frac{Y_{t}^{F}}{Y_{t-1}^{F}}-1=Q_{t}^{F}-1=\sum_{i}^{N} w_{i t-1}^{F}\left(\frac{q_{i t}}{q_{i t-1}}-1\right)=\sum_{i}^{N} g_{i t}^{F},
$$

where $g_{i t}^{F}=w_{i t-1}^{F}\left(q_{i t} / q_{i t-1}-1\right)$ is sector $i$ 's additive growth contribution published by BEA and $w_{i t-1}^{F}$ is the Fisher weight such that $Q_{t}^{F}=\sum_{i}^{N} w_{i t-1}^{F}\left(q_{i t} / q_{i t-1}\right)$. So instead of using the published disaggregated real value-added data directly, we sum up each sector's contribution to growth and thereby obtain the growth contribution of two larger sectors: $g_{K t}=\sum_{i \in K \text { Sector }} g_{i t}^{F}$ and $g_{L t}=\sum_{i \in L \text { Sector }} g_{i t}^{F}$. The real value-added of each of these two larger sectors is then calculated, for $j=K, L$, as $Y_{j t}=Y_{j b}+$ $\sum_{s=b}^{t} R G D P_{s-1} g_{j s}$ after the base year and $Y_{j t}=Y_{j b}-\sum_{s=t}^{b-1} R G D P_{s} g_{j s+1}$ before the base year; here, $b$ denotes the base year (2005) and RGDP abbreviates real gross domestic product.

Other countries' industry data are taken from the OECD STAN database, which publishes annual estimates of sectoral input and output data at the ISIC two-four-digit level for 31 countries. However, we are able to construct a set of internationally comparable industries only for a smaller set of countries and at the relatively more aggregated sector level. In the end, we have a much smaller number (32) of industries at the two-three-digit ISIC level for each country. Another drawback of the OECD STAN database is that even though it dates back to 1970 , most major industrial countries do not report detailed sectoral data before 1992. For each country, we estimate the country-sector-specific capital share as 1 - Labor cost/(Value-added - Net operating profit - Taxes less subsidies). ${ }^{27}$ To be consistent with our model, where goods across countries within the same

\footnotetext{
${ }^{26}$ See also Dumagan (2010).

${ }^{27}$ Much as with evidence for the United States, the estimated capital shares vary substantially; here they range from 0.08 to 0.83 .
} 
Table A2-Evidence on the Countercyclical Share of Capital-Intensive Sectors (OECD economies)

\begin{tabular}{lccc}
\hline \hline Country & $\rho\left(l_{K} / l, y\right)$ & $\rho\left(y_{K} / y, y\right)$ & $\sigma\left(y_{l}\right) / \sigma\left(y_{k}\right)$ \\
\hline Austria & -0.561 & -0.703 & 1.604 \\
Canada & -0.434 & -0.737 & 1.309 \\
Denmark & -0.482 & -0.365 & 0.962 \\
Finland & -0.893 & -0.933 & 3.057 \\
France & -0.393 & -0.390 & 1.259 \\
Germany & -0.067 & -0.325 & 0.977 \\
Italy & -0.286 & -0.487 & 1.379 \\
Netherlands & -0.528 & -0.696 & 2.007 \\
Norway & -0.651 & -0.606 & 1.336 \\
Spain & -0.845 & -0.811 & 1.835 \\
United Kingdom & -0.656 & -0.582 & 1.502 \\
United States & -0.580 & -0.870 & 2.101 \\
Average & & & 1.611 \\
\hline
\end{tabular}

sector have identical factor proportions, we use the cross-country time average from these calculations. The detailed industries are then divided into two larger sectors according to their fixed capital shares, and input and output estimates are aggregated accordingly. Table A1 ranks sectors according to their factor intensity for the United States. To check that the ranking of sectors by factor intensity is similar across OECD countries, we compute the average factor intensity for 36 industries using OECD STAN data. The ranking of sectors by factor intensity is highly similar across OECD countries and also with the United States.

For OECD countries, evidence on the relationship between employment and value-added shares of the capital-intensive sector and business cycles is provided in Table A2.

Trade Data.-Disaggregated quarterly US trade data at the six-digit NAICS level are available from the website of the USITC for the period 1997:I-2011:IV, and they are available at the four-digit SIC level for the period 1989:I-2001:IV. We merge these trade data with NBER manufacturing industry data, which provides information on capital shares in industry value-added that is used to categorize the detailed trading sectors into different groups (for most cases, we consider two large groups: capital- and labor-intensive sectors). Therefore, only a subset of the trading sectors (i.e., manufacturing sectors) are included. ${ }^{28}$ Trade balance is defined as the difference between exports and imports divided by GDP. Export and import data are seasonally adjusted using the Census X-12 method.

We also obtain detailed industry price data on imports and exports from the USITC. Import and export price indices for capital- and labor-intensive sectors are constructed as the unweighted average of price changes of all disaggregated industries within each of the two large groups (but excluding outliers).

\footnotetext{
${ }^{28}$ Annual sector-level trade data are also available in Feenstra's "World Trade" dataset. However, that data is based on the SITC72 four-digit level, and there is no reliable way to construct capital intensity at that level. Hence this information is not used in our paper.
} 
Aggregate Statistics.-For the economy-wide statistics reported in Table 2, we use the annual (constant price-based) NIPA series of GDP, private consumption, private fixed asset formation, and exports and imports from the BEA. Employment data for the United States are obtained from the US Bureau of Labor Statistics. We calculate the international co-movement statistics using the average statistics for US-country pairs involving the United States and each of the following individual industrial countries: Australia, Austria, Canada, Denmark, Finland, France, Germany, Ireland, Italy, Japan, Korea, the Netherlands, Norway, Spain, Sweden, and the United Kingdom. For these countries, all data series are obtained from the OECD's National Account Statistics and Population and Employment Statistics. The sample period begins at 1970 and ends at 2013.

\section{Appendix B: Complete Markets Model}

To illustrate the core mechanism, we present a numerical illustration of a simple, complete markets model and then compare the one-sector with the two-sector economy.

Complete Asset Markets.-The complete markets economy assumes that a full set of state-contingent securities are traded. Let $B^{j}\left(s^{t}, s_{t+1}\right)$ denote $j$ 's holdings of a state-contingent bond purchased in period $t$ and state $s^{t}$ that pays one unit of consumption contingent on $s_{t+1}$ at $t+1$. Let $Q\left(s^{t+1} \mid s^{t}\right)$ denote the price of this bond in period $t$ and state $s^{t}$. Agents in the two economies maximize their expected lifetime utilities, as given in equation (1), subject to the following constraints:

$$
\begin{aligned}
c^{j}\left(s^{t}\right)+ & I^{j}\left(s^{t}\right)+\sum_{s_{t+1}} Q\left(s^{t-1} \mid s^{t}\right) B^{j}\left(s^{t-1}\right) \\
& =B^{j}\left(s^{t}\right)+w^{j}\left(s^{t}\right) l^{j}\left(s^{t}\right)+r^{j}\left(s^{t}\right) K^{j}\left(s^{t-1}\right) ;
\end{aligned}
$$

here $w^{j}\left(s^{t}\right)$ and $r^{j}\left(s^{t}\right)$ are, respectively, the wage and the net return on capital in country $j$. Clearing of the international bond market requires that $\sum_{j} B^{j}\left(s^{t}\right)=0$ for all $s^{t}$.

To demonstrate that the structure of asset markets does not affect the key mechanisms we study - and to abstract from other, possibly confounding factorswe examine the impulse responses given in the simplest case possible: one where asset markets are complete, aggregate labor is exogenous $\left(l_{t}=\bar{l}\right.$ and $\left.\nu=1\right)$, and only productivity shocks are present. We ensure that there is no other impetus for positive co-movement by assuming zero correlation in innovations across countries: $\operatorname{corr}\left(\varepsilon^{H}, \varepsilon^{F}\right)=0$. The other relevant structural parameters are set at their standard levels: $\beta$ is set to 0.95 (at annual frequency), the risk aversion parameter $\sigma$ is set to 2 , and the depreciation rate $\delta$ is set to 0.1 . Calibration of the other parameters is explicated in Section IIA of the main text, but for purposes of illustration we, here, choose $\alpha_{k}=0.59, \alpha_{l}=0.16, \gamma_{l}=0.56, \eta_{l}=1.673$, and $\eta_{k}=1$. The adjustment cost parameter is chosen such that investment volatility relative to output volatility matches the data. 
Panel A. Home K-int employment share

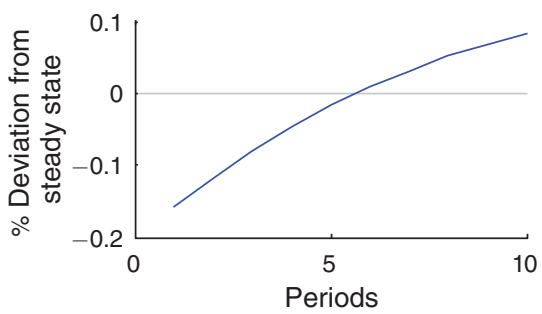

Panel C. Home K-int output share

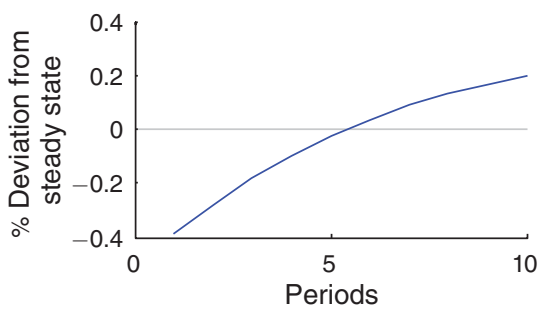

Panel E. K-int goods relative price $\left(P_{k} / P_{l}\right)$

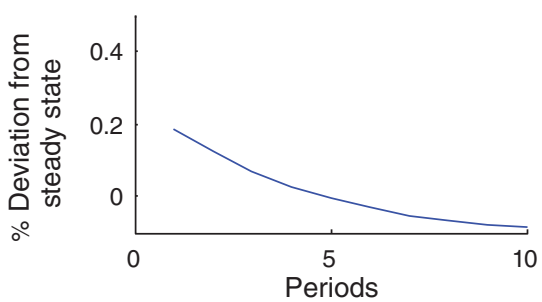

Panel B. Foreign K-int employment share

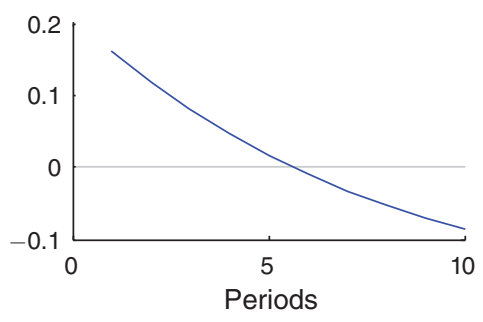

Panel D. Foreign K-int output share

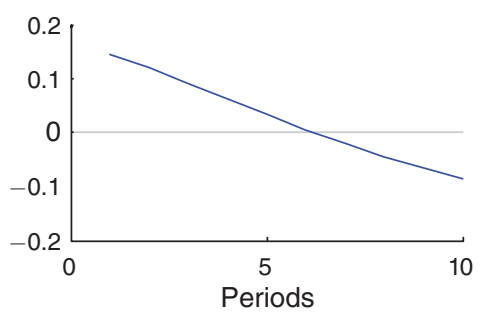

Panel F. Home productivity

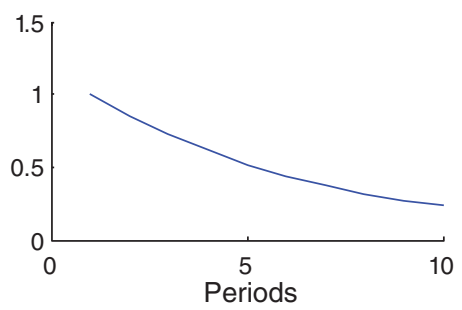

Figure B1. Impulse Responses to a Home Productivity Shock (two-sector model)-Sectoral Variables

\section{Appendix C: Estimation}

We adopt Bayesian methods to estimate the log-linearized model described in Section I by fitting it to annual US data. Bayesian methods have several merits compared to calibration. First, it uses general equilibrium conditions rather than partial equilibrium models or reduced form equations, which improves on the identification as discussed in Leeper and Zha (2000). Second, it performs better than General Methods of Moments methods for small sample estimations.

\section{A. Benchmark Model}

Calibrated Parameters.-A certain number of parameters are kept fixed throughout the estimation. We obtain the values of these parameters by calibrating the model to match the steady-state values of some observables. The discount factor 
Panel A. Home consumption

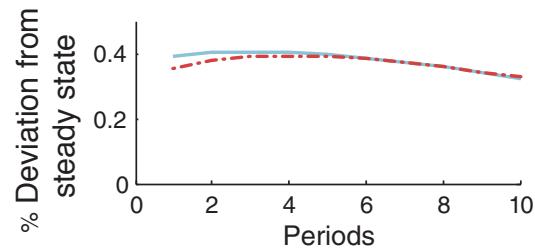

Panel C. Home investment

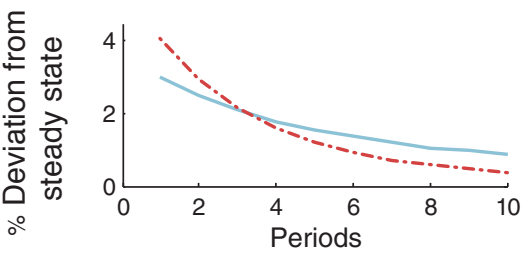

Panel E. Home output

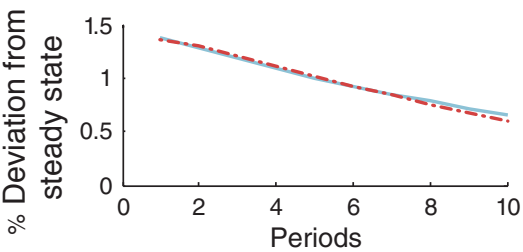

Panel G. Home net export

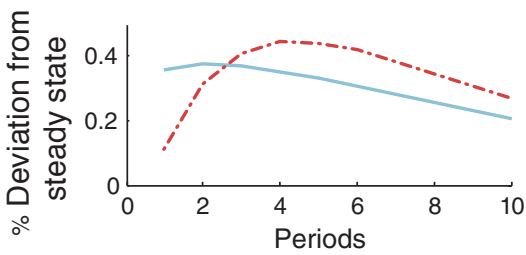

Panel B. Foreign consumption

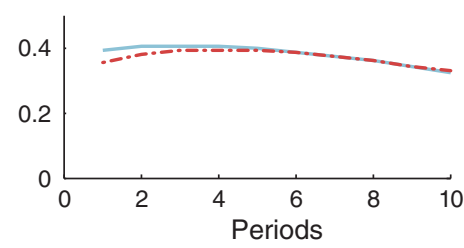

Panel D. Foreign investment

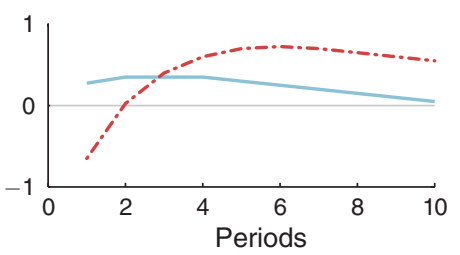

Panel F. Foreign output

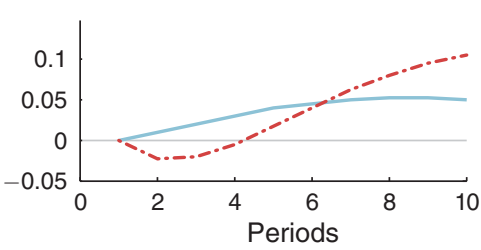

Panel H. Home productivity

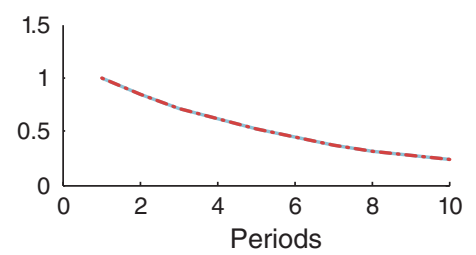

Two sectors

One sector

Figure B2. Impulse Responses to a Home Productivity Shock-Economy-Wide Variables

$\beta$ is set to 0.95 , which implies a nominal annual interest rate of 5 percent. The risk aversion parameter $\sigma$ is set at 2, which is standard in the literature. The elasticity of the labor supply, $\psi$, is set to 2.44 , and we put $\kappa=2.75$ to match previously reported evidence on labor supply elasticity (Pistaferri 2003). The capital-intensive sector's share in total value-added, $\gamma_{k}=0.44$, is calculated from the data. Capital intensities in capital- and labor-intensive sectors are computed as $\alpha_{k}=0.59$ and $\alpha_{l}=0.16$, respectively (see the main text). To match the sample mean of the investment/output ratio, the depreciation rate $\delta$ is set to 0.1 . The cross-country correlation is set at 0.25 to be comparable with existing studies.

Data.-We estimate the rest of the structural parameters, $\left\{\nu, \theta, \eta_{l}, b_{k}, b_{l}, \rho_{z}, \sigma_{z}\right.$, $\left.\rho_{\lambda}, \sigma_{\lambda}\right\}$, and we use US observations on real consumption, real private domestic 
investment, and real value-added of the capital-intensive and labor-intensive sectors $\left(\left\{C, I, Y_{k}, Y_{l}\right\}\right)$ from 1977-2013 as four targets. Consumption and investment data are obtained from from US BEA NIPA dataset. Data series on sectoral real value-added output are obtained from BEA industrial production database. All data series are HP-filtered with a smoothing parameter of 100 . We then obtain the cyclical components of each variable and match them to the difference between the logarithm of the corresponding model variables and their steady states.

The Priors. - We choose priors of the estimated parameters in a wide domain that is comparable to values commonly used in the literature (e.g., Smets and Wouters 2003). In particular, we assume a Beta distribution for all the parameters with domain between 0 and 1 , which includes the persistence parameters of the shock processes $\rho_{\lambda}$ and $\rho_{z}$ as well as the preference parameter $\nu$, which disciplines the income effect of labor supply. The prior mean for $\nu$ is set at 0.5 , which is between the extreme values in the case of $\operatorname{GHH}(\nu=0)$ and $\operatorname{KPR}(\nu=1)$. We use the inverse Gamma distribution for the parameters with positive values; these include the standard deviation of the technology shock $\sigma_{\lambda}$ and the preference shock $\sigma_{z}$, the elasticity of shocks in the labor intensive sector with respect to the aggregate shock, $\eta_{l}$, and the elasticity of substitution between labor-intensive and capital-intensive goods in the final sector, $\theta$. Our choices of the means and variances of shock persistence and volatility are quite uninformational. The prior mean for $\eta_{l}$ is chosen such that the aggregate shock has the same effect on both labor- and capital-intensive sectors. We use the Normal distribution for $b_{k}$ and $b_{l}$. The structural parameters to be estimated and their associated prior distributions are listed in Table $\mathrm{C} 1$.

The Posteriors.-Table $\mathrm{C} 1$ also summarizes the estimates of structural and shock parameters at posterior mode with 90 percent probability intervals (the last column). The preference parameter $\nu$ is estimated to be 0.735 , which implies a fairly large income effect of consumption on labor supply. The estimated elasticity is 0.517 . The estimated persistence of a technology shock is 0.590 , which is a rather low level. The adjustment cost of investments in the capital-intensive sector is lower than that for the labor-intensive sector. The sensitivity of shocks to production in the labor-intensive sector is 67 percent higher than in the capital-intensive sector, which agrees with our observation that labor-intensive sectors tend to disproportionately expand (contract) during booms (busts).

Estimated Preference and Technology Shocks.-Figure C1 shows the estimated aggregate demand and technology shocks derived from our Bayesian estimation. The time series of Home technology shocks is highly correlated with US business cycles.

\section{B. Models Used for Sensitivity Analysis}

Different Combinations of Shocks.-Section IIC considers alternative combinations of shocks as a test of the model's robustness. We re-estimate the model parameters for each case using Bayesian methods to fit the exact same four US 
Table C1-Prior and Posterior Distribution of Parameters

\begin{tabular}{|c|c|c|c|c|c|c|c|}
\hline \multirow[b]{2}{*}{ Parameter } & \multirow[b]{2}{*}{ Description } & \multicolumn{3}{|c|}{ Prior } & \multicolumn{3}{|c|}{ Posterior } \\
\hline & & Density & Mean & SD & Mode & SD & {$[5$ th, 95 th $]$} \\
\hline$\nu$ & Preference & Beta & 0.5 & 0.15 & 0.7353 & 0.0957 & {$[0.6130,0.9045]$} \\
\hline$\theta$ & $\begin{array}{l}\text { Elasticity of } \\
\text { substitution }\end{array}$ & Inverse gamma & 0.99 & 0.5 & 0.5169 & 0.0864 & {$[0.4994,0.7549]$} \\
\hline$b_{k}$ & $\begin{array}{l}\text { Adjustment cost in } \\
\text { sector } k\end{array}$ & Normal & 0.5 & 0.5 & 0.1141 & 0.0344 & {$[0.0747,0.1913]$} \\
\hline$b_{l}$ & $\begin{array}{l}\text { Adjustment cost in } \\
\text { sector } l\end{array}$ & Normal & 0.5 & 0.5 & 0.6371 & 0.2419 & {$[0.1560,0.6240]$} \\
\hline$\rho_{z}$ & Persistence in $z_{t}$ & Beta & 0.5 & 0.15 & 0.5899 & 0.0791 & {$[0.4713,0.7273]$} \\
\hline$\rho_{\lambda}$ & Persistence in $\lambda_{t}$ & Beta & 0.5 & 0.15 & 0.46 & 0.0758 & {$[0.3709,0.5706]$} \\
\hline$\sigma_{z}$ & $\mathrm{SD}$ in shocks to $z_{t}$ & Inverse gamma & 0.05 & 0.1 & 0.0135 & 0.0016 & {$[0.0122,0.0165]$} \\
\hline$\sigma_{\lambda}$ & $\mathrm{SD}$ in shocks to $\lambda_{t}$ & Inverse gamma & 0.05 & 0.1 & 0.028 & 0.0027 & {$[0.0282,0.0386]$} \\
\hline$\eta_{l}$ & $\begin{array}{l}\text { Elasticity to } \\
\text { aggregate shocks }\end{array}$ & Inverse gamma & 1 & 1 & 1.6725 & 0.1175 & {$[1.5264,1.7723]$} \\
\hline
\end{tabular}

Note: The reported time series are percentage deviations from the steady state.

time series: real value-added in capital- and labor-intensive sectors, in consumption, and in investment. To save space, Table $\mathrm{C} 2$ reports only the posterior mode of the estimated parameters corresponding to each column of Table 3; the priors are similar to those postulated in Table $\mathrm{C} 1$.

Non-tradables.-After calibrating to data that include capital-intensive and labor-intensive tradables sectors and non-tradables sectors, we obtain $\alpha_{N}=0.35$ and $\gamma_{N}=0.45$ for the latter. ${ }^{29}$ Dividing the tradables sectors into capital and labor-intensive sectors (in a similar fashion as before) yields $\gamma_{k}=0.10$, $\alpha_{l}=0.61$, and $\alpha_{k}=0.25$. The extant literature focuses on low values of the elasticity of substitution $\zeta$-that is, ranging from 0 to 1 for industrialized countries (see Coeurdacier 2009); we adopt the value $\zeta=0.55$ (as in Stockman and Tesar 1995). The other previously calibrated parameters remain the same as before. Given these parameters, we estimate the remaining ones (i.e., $\left\{\nu, \theta, \eta_{l}, b_{k}, b_{l}, b_{N}\right.$, $\rho_{z}, \sigma_{z}, \rho_{\lambda}, \sigma_{\lambda}, \rho_{N}$, and $\left.\left.\sigma_{N}\right\}\right)$ using Bayesian methods, much as before. Since we now have one more shock process - namely, the productivity shock to the non-tradables sector, $\log A_{N, t}$-we can incorporate one more observation from the data. Therefore, the model is now estimated to fit five observations: three of sectoral real value-added data $\left(Y_{l}, Y_{k}, Y_{N}\right)$ and two aggregate observations as before $(C, I)$. Our choices of the prior distribution are the same as in the two-sector case.

Table C3 presents the prior distribution as well as the estimated results. Similarly to the two-sector case, $\nu$ is estimated to be 0.44 and so allows for a significant income effect. The elasticity of substitution between capital- and labor-intensive goods is 0.514 , which is fairly close to the previous estimation. The labor-intensive tradables sector is much more responsive to an aggregate shock than is the capital-intensive

${ }^{29}$ We follow Stockman and Tesar (1995) in defining the tradables and non-tradables sectors. 
Panel A. Home preference shocks

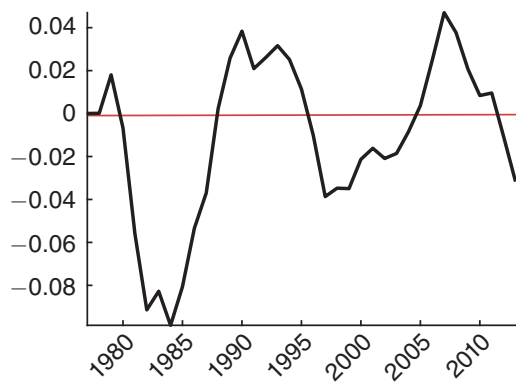

Panel C. Home technology shocks

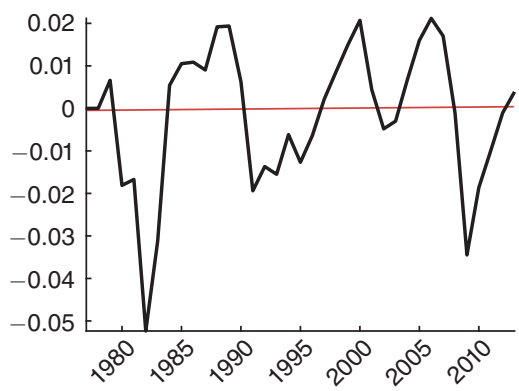

Panel B. Foreign preference shocks

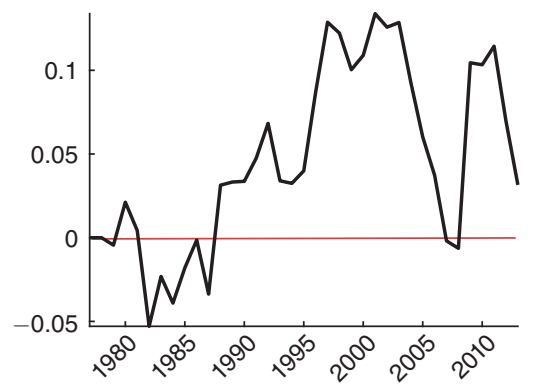

Panel D. Foreign technology shocks

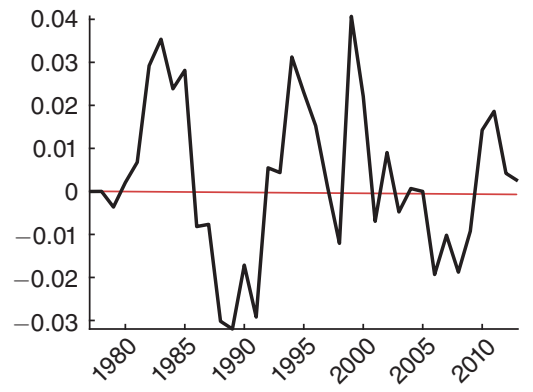

Figure C1. Time Series of Estimated Shocks (deviations from the steady state)

Table C2-Parameter Values for Alternative Combinations of Shocks

\begin{tabular}{|c|c|c|c|c|}
\hline Parameter & $\begin{array}{c}\text { Asymmetric } \\
\text { shocks } \\
(1)\end{array}$ & $\begin{array}{l}\text { Asymmetric } \\
\text { tastes } \\
(2)\end{array}$ & $\begin{array}{l}\text { Symmetric } \\
\text { shocks } \\
(3)\end{array}$ & $\begin{array}{c}\text { Idiosyncratic } \\
\text { productivity } \\
\text { (4) }\end{array}$ \\
\hline$\nu$ & 0.442 & 0.3203 & 0.643 & 0.6277 \\
\hline$\theta$ & 0.6014 & 0.5334 & 0.4489 & 0.5365 \\
\hline$b_{k}$ & 0.1169 & 0.1172 & 0.1173 & 0.5098 \\
\hline$b_{l}$ & 0.5256 & 0.4067 & 0.4078 & 0.1363 \\
\hline$\eta_{l}$ & 1.6522 & 1 & 1 & 1.1854 \\
\hline$\zeta_{k}$ & 1 & 1 & - & - \\
\hline$\zeta_{l}$ & 0.5331 & 0.5527 & - & - \\
\hline$\rho_{z}$ & 0.5535 & 0.3523 & 0.3702 & 0.7622 \\
\hline$\sigma_{z}$ & 0.013 & 0.0295 & 0.032 & 0.0133 \\
\hline$\rho_{\lambda}$ & 0.6624 & 0.4929 & 0.4366 & 0.5461 \\
\hline$\sigma_{\lambda}$ & 0.0181 & 0.0165 & 0.0268 & 0.0185 \\
\hline$\rho_{d}$ & 0.2732 & 0.2731 & - & - \\
\hline$\sigma_{d}$ & 0.0122 & 0.0123 & - & - \\
\hline$\rho_{k}$ & - & - & - & 0.4685 \\
\hline$\sigma_{k}$ & - & - & - & 0.0111 \\
\hline$\rho_{l}$ & - & - & - & 0.5318 \\
\hline$\sigma_{l}$ & - & - & - & 0.0121 \\
\hline
\end{tabular}


TABle C3-Prior and Posterior Distribution of Parameters

\begin{tabular}{|c|c|c|c|c|c|c|c|}
\hline \multirow[b]{2}{*}{ Parameter } & \multirow[b]{2}{*}{ Description } & \multicolumn{3}{|c|}{ Prior } & \multicolumn{3}{|c|}{ Posterior } \\
\hline & & Density & Mean & SD & Mode & SD & {$[5$ th, 95 th $]$} \\
\hline$\nu$ & Preference & Beta & 0.5 & 0.15 & 0.4406 & 0.076 & {$[0.2790,0.5196]$} \\
\hline$\theta$ & $\begin{array}{l}\text { Elasticity of } \\
\text { substitution }\end{array}$ & Inverse gamma & 0.99 & 0.5 & 0.5140 & 0.0947 & {$[0.4106,0.5768]$} \\
\hline$b_{k}$ & $\begin{array}{l}\text { Adjustment cost in } \\
\text { sector } k\end{array}$ & Normal & 0.5 & 0.5 & 0.6370 & 0.1916 & {$[0.5588,1.0276]$} \\
\hline$b_{l}$ & $\begin{array}{l}\text { Adjustment cost in } \\
\text { sector } l\end{array}$ & Normal & 0.5 & 0.5 & 0.8231 & 0.1942 & {$[0.5236,1.4528]$} \\
\hline$b_{N}$ & $\begin{array}{l}\text { Adjustment cost in } \\
\text { sector } N\end{array}$ & Normal & 0.5 & 0.5 & 1.4934 & 0.2597 & {$[1.2704,1.7334]$} \\
\hline$\rho_{z}$ & Persistence in $z_{t}$ & Beta & 0.5 & 0.15 & 0.2201 & 0.0814 & {$[0.0777,0.3837]$} \\
\hline$\rho_{\lambda}$ & Persistence in $\lambda_{t}$ & Beta & 0.5 & 0.15 & 0.5166 & 0.0698 & {$[0.4735,0.6092]$} \\
\hline$\rho_{N}$ & $\begin{array}{l}\text { Persistence in } \\
\quad \log A_{N, t}\end{array}$ & Beta & 0.5 & 0.15 & 0.6272 & 0.0694 & {$[0.4490,0.7055]$} \\
\hline$\sigma_{z}$ & $\mathrm{SD}$ in shocks to $z_{t}$ & Inverse gamma & 0.05 & 0.1 & 0.0210 & 0.0052 & {$[0.0145,0.0278]$} \\
\hline$\sigma_{\lambda}$ & $\mathrm{SD}$ in shocks to $\lambda_{t}$ & Inverse gamma & 0.05 & 0.1 & 0.0246 & 0.003 & {$[0.0213,0.0321]$} \\
\hline$\sigma_{N}$ & $\begin{array}{l}\text { SD in shocks to } \\
\quad \log A_{N, t}\end{array}$ & Inverse gamma & 0.05 & 0.1 & 0.0328 & 0.0032 & {$[0.0279,0.0359]$} \\
\hline$\eta_{l}$ & $\begin{array}{l}\text { Elasticity to } \\
\quad \text { aggregate shocks }\end{array}$ & Inverse gamma & 1 & 1 & 1.9767 & 0.4452 & {$[1.6040,3.0016]$} \\
\hline
\end{tabular}

tradables sector: $\eta_{l}$ is estimated to be 1.977. Shocks to the tradables sector persist longer than do shocks to the non-tradables sector $\left(\rho_{z}<\rho_{N}\right)$, but the volatility of nontradables-specific shocks is higher $\left(\sigma_{N}>\sigma_{z}\right)$.

\section{REFERENCES}

- Backus, David K., Patrick J. Kehoe, and Finn E. Kydland. 1992. "International Real Business Cycles." Journal of Political Economy 100 (4): 745-75.

Backus, David K., Patrick J. Kehoe, and Finn E. Kydland. 1994. "Dynamics of the Trade Balance and the Terms of Trade: The J-curve?" American Economic Review 84 (1): 84-103.

-Backus, David K., and Gregor W. Smith. 1993. "Consumption and real exchange rates in dynamic economies with non-traded goods." Journal of International Economics 35 (3-4): 297-316.

- Baxter, Marianne, and Mario J. Crucini. 1995. "Business Cycles and the Asset Structures of Foreign Trade." International Economic Review 36 (4): 821-54.

- Benigno, Gianluca, and Christoph Thoenissen. 2008. "Consumption and real exchange rates with incomplete markets and non-traded goods." Journal of International Money and Finance 27 (6): 926-48.

- Burstein, Ariel, Christopher Kurz, and Linda Tesar. 2008. "Trade, production sharing and the international transmission of business cycles." Journal of Monetary Economics 55 (4): 775-95.

- Campolmi, Alessia, and Stefano Gnocchi. 2016. "Labor market participation, unemployment and monetary policy." Journal of Monetary Economics 79: 17-29.

-Christiano, Lawrence J., Roberto Motto, and Massimo Rostagno. 2014. "Risk Shocks." American Economic Review 104 (1): 27-65.

- Coeurdacier, Nicolas. 2009. "Do trade costs in goods market lead to home bias in equities?" Journal of International Economics 77 (1): 86-100.

Corsetti, Giancarlo, Luca Dedola, and Sylvain Leduc. 2008. "International Risk Sharing and the Transmission of Productivity Shocks." Review of Economic Studies 75 (2): 443-73.

-Cuñat, Alejandro, and Marco Maffezzoli. 2004. "Heckscher-Ohlin business cycle." Review of Economic Dynamics 7 (3): 555-85. 
Dumagan, Jesus C. 2010. "Computing Additive Chained Volume Measures of GDP Subaggregates." Philippine Institute for Development Studies Discussion Paper 2010-16.

-Engel, Charles, and Jian Wang. 2011. "International trade in durable goods: Understanding volatility, cyclicality, and elasticities." Journal of International Economics 83 (1): 37-52.

-Ghironi, Fabio, and Marc J. Melitz. 2005. "International Trade and Macroeconomic Dynamics with Heterogeneous Firms." Quarterly Journal of Economics 120 (3): 865-915.

- Gollin, Douglas. 2002. "Getting Income Shares Right.” Journal of Political Economy 110 (2): 458-74.

Greenwood, Jeremy, Zvi Hercowitz, and Gregory W. Huffman. 1988. "Investment, Capacity Utilization, and the Real Business Cycle." American Economic Review 78 (3): 402-17.

- Heathcote, Jonathan, and Fabrizio Perri. 2002. "Financial autarky and international business cycles." Journal of Monetary Economics 49 (3): 601-27.

-Jaimovich, Nir, and Sergio Rebelo. 2009. "Can News about the Future Drive the Business Cycle?" American Economic Review 99 (4): 1097-1118.

- Jin, Keyu. 2012. "Industrial Structure and Financial Capital Flows." American Economic Review 102 (5): 2111-46.

Jin, Keyu, and Nan Li. 2018. "International Transmission with Heterogeneous Sectors: Dataset." American Economic Journal: Macroeconomics. https://doi.org/10.1257/mac.20150379.

- Justiniano, Alejandro, Giorgio E. Primiceri, and Andrea Tambalotti. 2011. "Investment shocks and the relative price of investment." Review of Economic Dynamics 14 (1): 102-21.

-Karabarbounis, Loukas. 2014. "Home production, labor wedges, and international business cycles." Journal of Monetary Economics 64: 68-84.

Kehoe, Patrick J., and Fabrizio Perri. 2002. "International Business Cycles with Endogenous Incomplete Markets." Econometrica 70 (3): 907-28.

King, Robert G., Charles I. Plosser, and Sergio T. Rebelo. 1988. "Production, growth and business cycles: I. The basic neoclassical model." Journal of Monetary Economics 21 (2-3): 195-232.

-Kollmann, Robert. 1996. "Incomplete asset markets and the cross-country consumption correlation puzzle." Journal of Economic Dynamics and Control 20 (5): 945-61.

Leeper, Eric M., and Tao A. Zha. 2000. "Assessing Simple Policy Rules: A View from a Complete Macro Model." Federal Reserve Bank of Atlanta Working Paper 200-19.

-Melitz, Marc J. 2003. "The Impact of Trade on Intra-Industry Reallocations and Aggregate Industry Productivity." Econometrica 71 (6): 1695-1725.

NBER-CES Manufacturing Industry Database. 2013. National Bureau of Economic Research. http:// www.nber.org/data/nbprod2005.html.

-Pistaferri, Luigi. 2003. "Anticipated and Unanticipated Wage Changes, Wage Risk, and Intertemporal Labor Supply." Journal of Labor Economics 21 (3): 729-54.

-Samaniego, Roberto M., and Juliana Y. Sun. 2015. "Technology and contractions: Evidence from manufacturing." European Economic Review 79: 172-95.

-Schmitt-Grohé, Stephanie, and Martin Uribe. 2012. "What's News in Business Cycles." Econometrica 80 (6): 2733-64.

-Schott, Peter K. 2003. "One Size Fits All? Heckscher-Ohlin Specialization in Global Production." American Economic Review 93 (3): 686-708.

-Smets, Frank, and Raf Wouters. 2003. "An Estimated Dynamic Stochastic General Equilibrium Model of the Euro Area." Journal of the European Economic Association 1 (5): 1123-75.

Stockman, Alan C., and Linda L. Tesar. 1995. "Tastes and Technology in a Two-Country Model of the Business Cycle: Explaining International Comovements." American Economic Review 83 (1): $168-85$. 